REVISTA
DA
FUNDARTE

\title{
TEXTO E IMAGEM EM DIÁLOGO: MODOS DE APROPRIAÇÃO DA CULTURA POR UMA JOVEM COM TRANSTORNO DO ESPECTRO DO AUTISMO
}

\author{
Lucia Helena Reily \\ Adriana Lia Friszman de Laplan \\ Débora Dainez
}

DOI: $10.19179 / 2319-0868.786$

REILY, Lucia Helena; LAPLAN, Adriana Lia Friszman de; DAINEZ, Débora. Texto e imagem em diálogo: modos de apropriação da cultura por uma jovem com transtorno do espectro do autismo Revista da FUNDARTE. Montenegro, p.01-32, ano 20, oㅡ 42, julho/setembro de 2020.

Disponível em: http://.seer.fundarte.rs.gov.br/index.php/RevistadaFundarte/index> 30 de setembro de 2020 


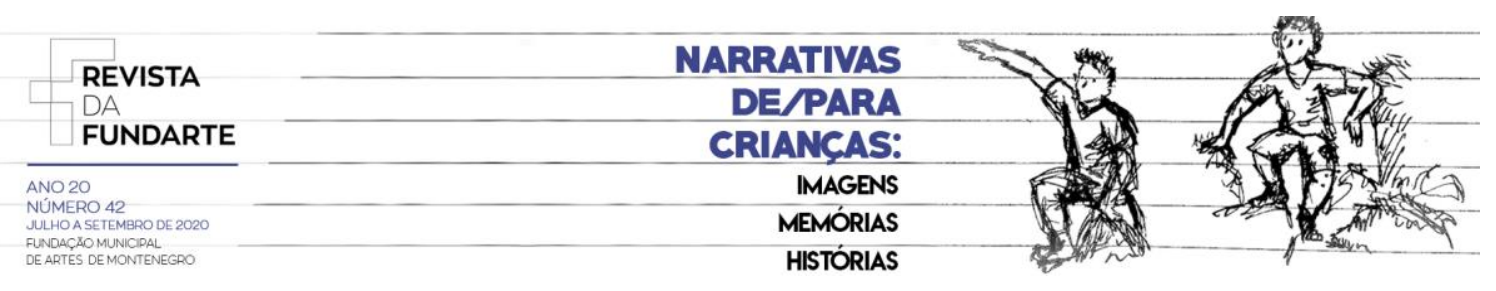

\title{
TEXTO E IMAGEM EM DIÁLOGO: MODOS DE APROPRIAÇÃO DA CULTURA POR UMA JOVEM COM TRANSTORNO DO ESPECTRO DO AUTISMO
}

\author{
Lucia Helena Reily ${ }^{1}$ \\ Adriana Lia Friszman de Laplan² \\ Débora Dainez ${ }^{3}$
}

\begin{abstract}
Resumo: A linguagem torna o ser humano capaz de um desenvolvimento de caráter cultural, responsável pela criação de processos simbólicos e de diferentes tipos de produtos, como textos e imagens que circulam socialmente. As particularidades dos modos de apropriação desses processos podem informar a compreensão sobre a interação dos sujeitos com os objetos de cultura e sobre as formas em que estes afetam o processo de desenvolvimento. O presente trabalho reflete sobre um corpus de registros de atividades de leitura, escrita e desenho, realizadas no contexto de aulas de arte, das quais participou uma adolescente com diagnóstico de Transtorno do Espectro Autista. $\mathrm{O}$ estudo analisa os modos de apropriação da escrita e da imagem e indaga sobre as possibilidades que cada suporte oferece no sentido de promover o desenvolvimento e a aprendizagem, a fruição, a criatividade e a participação na cultura.
\end{abstract}

Palavras-chave: Ensino de Artes Visuais; Desenvolvimento Cultural; Transtorno do Espectro Autista.

\section{TEXT AND IMAGES IN DIALOGUE: MODES OF APPROPRIATING CULTURE BY A YOUNG PERSON WITH AUTISM SPECTRUM DISORDER}

\begin{abstract}
Language enables human beings to develop culturally. The cultural nature of development is responsible for the creation of symbolic processes and different kinds of products, such as texts and images that circulate socially. The specific features of the modes of appropriation of these processes can inform understanding about how people interact with cultural objects and about the ways these in turn affect developmental processes. This article reflects on a corpus of material collected during reading, writing and artmaking activities that were carried out with a teenage girl diagnosed with Autism Spectrum Disorder within the context of weekly art classes. The study analyses modes of appropriation of writing and image making and inquires upon the possibilities that each semiotic system offers towards promoting development and learning, fruition, creativity and cultural participation.
\end{abstract}

\footnotetext{
1 É arte-educadora, professora na Universidade Estadual de Campinas. Graduada com Bacharel em Artes pela Universidade de Indiana, EUA, com revalidação em Educação Artística pela Pontifícia Universidade Católica de Campinas. Fez mestrado e doutorado em Psicologia Escolar na Universidade de São Paulo e livre docência em Linguagem na Universidade Estadual de Campinas. Realiza pesquisas na área de ensino de Artes Visuais e Estudos da Deficiência.

2 Pedagoga, mestre e doutora em Educação e livre docente em Desenvolvimento Humano pela Universidade Estadual de Campinas. Docente do curso de Fonoaudiologia da Faculdade de Ciências Médicas da Universidade Estadual de Campinas, estuda e pesquisa temas relacionados ao Desenvolvimento Humano, Educação Inclusiva, aquisição da linguagem oral e escrita e a políticas e práticas de educação.

${ }^{3}$ Fonoaudióloga, mestre em Educação pela Universidade Metodista de Piracicaba, doutora em Educação pela Universidade Estadual de Campinas. Pós Doutoranda do Programa de PósGraduação Saúde, Interdisciplinaridade e Reabilitação da Faculdade de Ciências Médicas da Universidade Estadual de Campinas, estuda e pesquisa temas relacionados ao Desenvolvimento Humano, Linguagem, Educação Especial e Inclusiva, Perspectiva Histórico-Cultural. Docente do Departamento de Ciências Humanas e Educação (DCHE) da Universidade Federal de São Carlos Campus Sorocaba.
}

REILY, Lucia Helena; LAPLAN, Adriana Lia Friszman de; DAINEZ, Débora. Texto e imagem em diálogo: modos de apropriação da cultura por uma jovem com transtorno do espectro do autismo Revista da FUNDARTE. Montenegro, p.01-32, ano 20, no 42, julho/setembro de 2020.

Disponível em: http://.seer.fundarte.rs.gov.br/index.php/RevistadaFundarte/index> 30 de setembro de 2020 


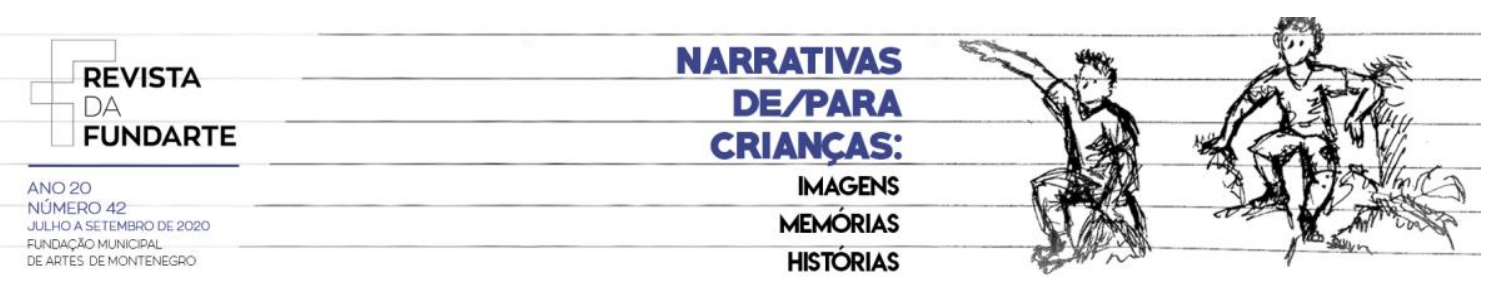

Keywords: Visual Arts Teaching; Cultural Development; Autism Spectrum Disorder.

\section{TEXTE ET IMAGE DANS LE DIALOGUE: MODES D'APPROPRIATION DE LA CULTURE PAR UNE JEUNE FILLE ATTEINT DE TROUBLE DU SPECTRE DE L'AUTISME}

Résumé: Le langage rend l'être humain capable d'un développement à caractère culturel, responsable de la création de processus symboliques et de différents types de produits, tels que des textes et des images qui circulent socialement. Les particularités des modes d'appropriation de ces processus peuvent éclairer la compréhension de l'interaction des sujets avec les objets de la culture et de la manière dont ils affectent le processus de développement. Le présent travail se penche sur un corpus de registres d'activités de lecture, d'écriture et de dessin, réalisées dans des cours d'art, auxquelles a participé un adolescent atteint de trouble du spectre de l'autisme. L'étude analyse les moyens de s'approprier l'écriture et l'image et examine les possibilités offertes par chaque soutien afin de promouvoir le développement et l'apprentissage, le plaisir, la créativité et la participation à la culture.

Mots-clés: Enseignement des Arts Visuels; Développement Culturel; Trouble du Spectre de l'Autisme.

\section{Introdução}

O presente estudo se debruça sobre os modos de apropriação e as possibilidades de criação de textos e imagens de uma adolescente com diagnóstico de Transtorno do Espectro do Autismo (TEA) no contexto de aulas de Arte. Buscamos perscrutar como o trabalho educacional mediado constitui 0 funcionamento e a organização das funções psíquicas, sustentando a emergência da atividade simbólica, criadora e conceitual. Para tanto, analisamos o papel da criação imaginária nos processos de aprendizagem e desenvolvimento e a sua potência para promover a inserção e a participação do sujeito na cultura.

O corpus aqui considerado é composto pelos registros das aulas, durante as quais foram realizadas atividades que envolviam a leitura e produção de textos e imagens. A análise enfoca a singularidade do processo de desenvolvimento humano e de construção de sentidos. A perspectiva que adotamos em relação a esse complexo problema se nutre das muitas reflexões no campo das Ciências Humanas, que nos alertam sobre o caráter social da linguagem, o estatuto do sujeito e da experiência vivida, os modos de apropriação de processos e objetos de cultura.

A compreensão do desenvolvimento humano como eminentemente simbólico e cultural atravessa as visões da filosofia e da psicologia do século XX. É possível 


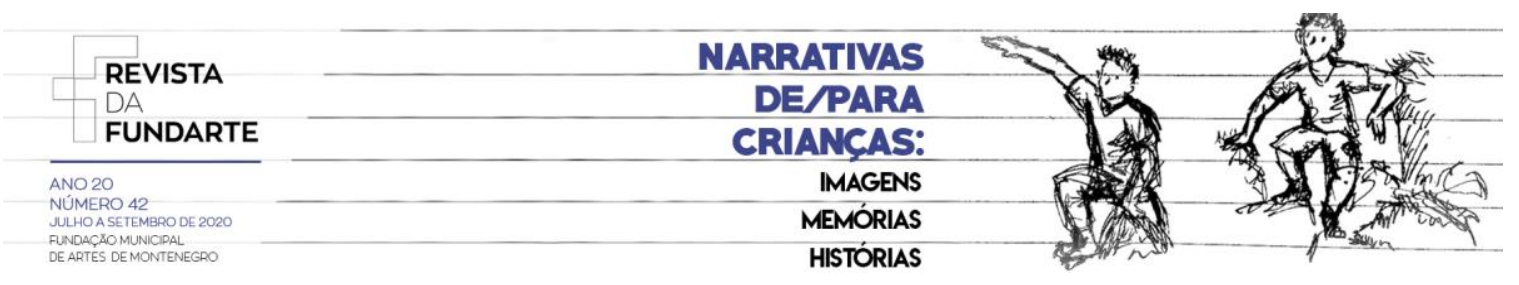

encontrar no pensamento do filósofo Ernst Cassirer a intrínseca articulação vidacultura-sistema simbólico-constituição do sujeito:

\begin{abstract}
Não estando mais num universo meramente físico, o homem vive em um universo simbólico. A linguagem, o mito, a arte e a religião são partes desse universo. São os variados fios que tecem a rede simbólica, o emaranhado da experiência humana. Todo progresso humano em pensamento e experiência é refinado por essa rede, e a fortalece. $O$ homem não pode mais confrontar-se com a realidade imediatamente; não pode vê-la, por assim dizer, frente a frente. A realidade física parece recuar em proporção ao avanço da atividade simbólica do homem. Em vez de lidar com as próprias coisas o homem está, de certo modo, conversando constantemente consigo mesmo. Envolveu-se de tal modo em formas linguísticas, imagens artísticas, símbolos místicos ou ritos religiosos que não consegue ver ou conhecer coisa alguma a não ser pela interposição desse meio artificial. Sua situação é a mesma tanto na esfera teórica como na prática. Mesmo nesta, o homem não vive em um mundo de fatos nus e crus, ou segundo suas necessidades e desejos imediatos. Vive antes em meio a emoções imaginárias, em esperanças e temores, ilusões e desilusões, em suas fantasias e sonhos. (CASSIRER, 1994, p. 2).
\end{abstract}

Anuncia-se nessa reflexão a complexidade do funcionamento simbólico impregnando o processo de humanização. Isso nos leva a abordar a infusão das dimensões cognitiva, linguística, afetiva-volitiva, artística e ética-estética na vida materializada no processo simbólico.

De modo a estender tais ideias refletindo sobre o processo de desenvolvimento da criança e do adolescente, encontramos na perspectiva históricocultural um território fértil para o aprofundamento das condições e possibilidades de humanização. L. S. Vigotski, referência maior da mencionada perspectiva, teoriza sobre o desenvolvimento cultural, fenômeno esse conduzido na atividade social compartilhada, que viabiliza a produção e a apropriação de artefatos, técnicas, símbolos, signos e sentidos contingenciados na história de relações e produções humanas.

Como pontua Angel Pino,

É próprio do funcionamento do simbólico, criado pelo próprio homem, permitir que realidades de ordens diferentes possam articular-se numa unidade dialética em que cada uma possa ser também a outra: a matéria adquirindo uma forma simbólica de existência, sem perder sua condição primeira, e o simbólico objetivando-se numa matéria. (2006, p.65).

REILY, Lucia Helena; LAPLAN, Adriana Lia Friszman de; DAINEZ, Débora. Texto e imagem em diálogo: modos de apropriação da cultura por uma jovem com transtorno do espectro do autismo Revista da FUNDARTE. Montenegro, p.01-32, ano 20, no 42, julho/setembro de 2020. 


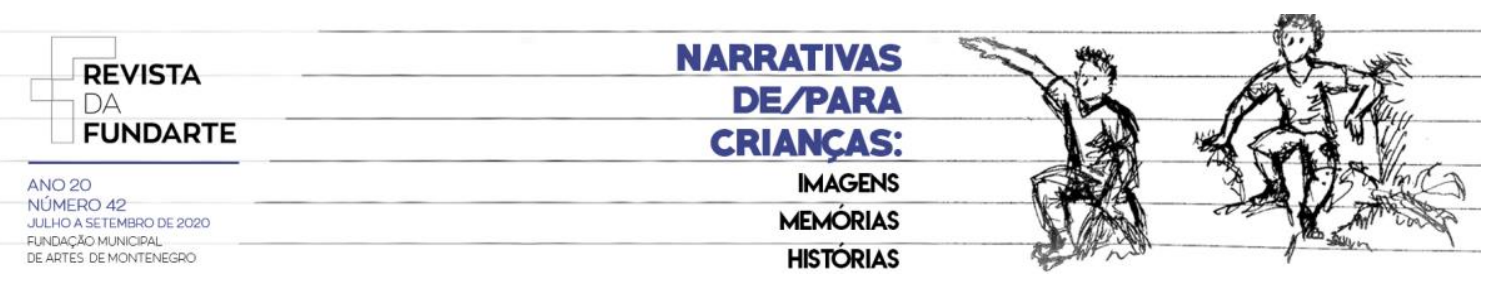

A condição primária de materialidade biológica que caracteriza a natureza humana é permanentemente agregada à condição simbólica, que possibilita atribuir sentido às coisas. No plano ontogenético, a imersão na cultura e a apropriação, pela criança, dos símbolos e dos signos de várias naturezas e dos seus sentidos sociais constitui, desse ponto de vista, o próprio processo de desenvolvimento das funções psíquicas de caráter mediado.

Vigotski, interessado na cultura como lócus de humanização, considerou nas suas formulações teóricas, as variantes dos processos psíquicos decorrentes de diferenças orgânicas, sensoriais, cognitivas e afetivas, para tecer as leis gerais de desenvolvimento humano, ressaltando o movimento de (trans)formação, a dinamicidade e a singularidade dos modos de constituição da pessoa. Dedicou parte dos seus estudos às pessoas com deficiência, mostrando, em cada caso, a importância de tornar disponíveis os meios culturais necessários para favorecer a aprendizagem e a participação social. O Braille, os materiais sonoros e táteis para a cegueira, a língua de sinais e os materiais visuais para os surdos, a linguagem tátil para os surdocegos e as estratégias de mediação para favorecer as condições de atenção, percepção, memória e elaboração de conceitos dos sujeitos com deficiência intelectual destacam-se entre as propostas para a promoção do desenvolvimento e da educação escolar dessa população.

Essas propostas, entretanto, longe de centrarem-se nas técnicas, métodos e recursos, enfatizam a função destes como formas de acesso aos processos simbólicos, como meios de apropriação e criação, considerando a importância do outro que interage, compartilha, estabelece relações de afeto e de troca. São esses os processos responsáveis pela inserção e participação do sujeito na cultura e, portanto, pelo seu desenvolvimento.

Ao chamar a atenção para as diversas vias de desenvolvimento psíquico que podem ser forjadas e mediadas nas relações sociais, Vigotski (1997) realça a atividade criadora como uma nova formação mediatizante de desenvolvimento cultural da criança com deficiência. A cultura, como aspecto fundacional da condição 


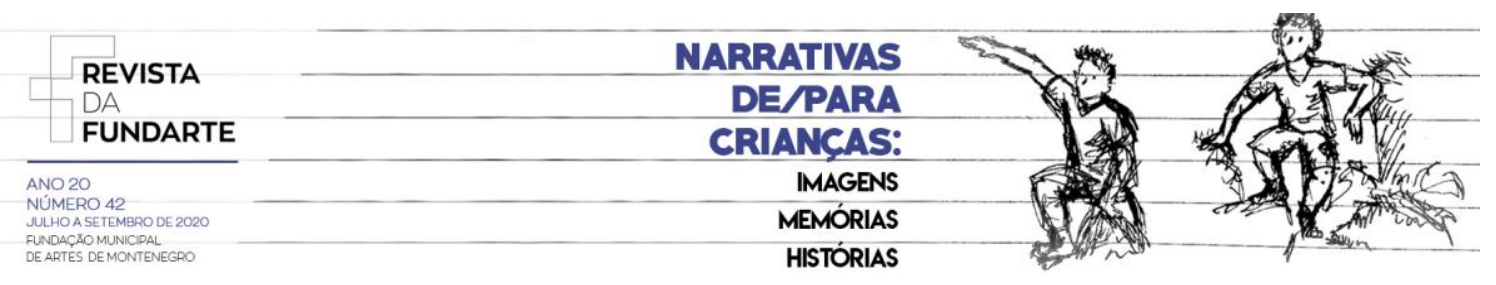

criativa do humano, permite reinventar novas formas de viver e de associar-se a outras pessoas. A vida coletiva alimenta, incessantemente, a vida singular, na medida em que permite projetar novas condições de organização social e de interação humana (MAHEIRIE, ZANELLA, 2017).

A concepção de uma relação constitutiva, perpassada pela experiência social e pela rede simbólica, de modo tal que a realidade física, ou melhor, a sua percepção, é profundamente afetada pelos processos de significação, nos leva a destacar a apropriação de imagens, sentidos, afetos, textos e ações como impulsionadora da atividade criadora, a qual repercute tanto no desenvolvimento cultural do pensamento do sujeito quanto na transformação da realidade.

A capacidade criadora, adquirida historicamente na relação de trabalho social, configura-se, assim, como um dos principais pilares de humanização (PINO, 2006). Os seres humanos agem sobre a natureza e produzem uma nova condição de existência material-simbólica, em função de objetivos coletivamente delineados. $O$ mesmo ato, origina, ancora e sustenta o processo de autotransformação.

A atividade criadora humaniza a natureza e o próprio homem. Desdobra-se em processos de autodeterminação, liberdade e consciência, os quais permitem assumir o rumo da própria evolução, tornar-se artífice do seu desenvolvimento e do desenvolvimento da sociedade (PINO, 2000; PINO, 2006; SHUARE, 2017). Essa esfera de produção constitui-se, portanto, enquanto requisito de toda produção material e simbólica, definindo a condição humana (PINO, 2006).

Um dos objetivos mais importantes da imaginação é a possibilidade de antecipar o resultado da atividade humana antes mesmo de iniciada, ou seja, de representar não só o produto final, mas os processos intermediários de produção. Em virtude disso, a imaginação regula toda a atividade material e simbólica (PETROVSKY, 2017).

Vigotski (2009) aborda a relação entre imaginação e realidade e afirma que a criação está atrelada à vivência significativa do sujeito no meio social, assim como ao contato com a experiência alheia. Toda criação imaginária constrói-se a partir da vivência do sujeito, por meio da qual, fatos são pinçados, recombinados, 


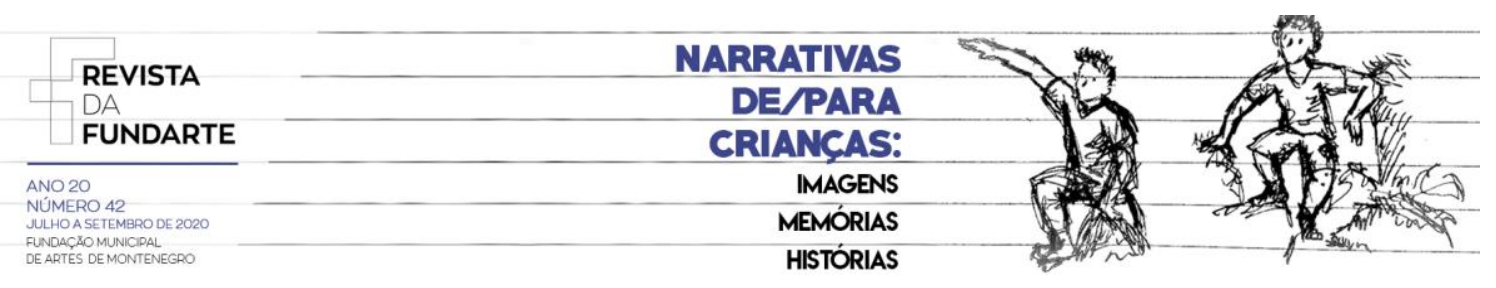

reelaborados. Esse processo também pode tomar por base a narrativa de outra pessoa, que serve como suporte para o sujeito imaginar algo novo. Haveria, assim, uma dependência mútua entre imaginação e vivência, quer dizer a imaginação criativa tanto toma da realidade a matéria sobre a qual opera, quanto produz novas realidades (CRUZ, 2015). Sobressai nessa dinâmica a participação do outro e a função da linguagem que permite o trânsito entre o sujeito e o meio social e amplia formas de vivenciar a realidade (VIGOTSKI, 1995).

Ao enfocar as novas formações psíquicas que emergem nas diferentes situações sociais de desenvolvimento ao longo da vida, Vigotski (1996) analisa como o exercício da imaginação está atrelado à linguagem e à vivencia à qual foi atribuído sentido. No que se refere ao período da adolescência, modifica-se a relação do sujeito com o meio social, novas vivências se estabelecem, novas necessidades e possibilidades se apresentam, o que repercute nos modos de significar, de aprender, de pensar, de agir, de participar da cultura.

Nesse período, o processo de pensamento visual, envolto nos afetos, se entretece de forma mais íntima com a designação semântica dos objetos, ou seja, a percepção impregnada de sentidos se generaliza em imagens conceituais, em representações imaginativas. A imaginação começa a se apoiar em conceitos, sendo esses constituídos pela/na linguagem em funcionamento nas práticas sociais. A percepção se converte em representação, imagens eidéticas tornam-se imagens conceituais, conceito verbal.

É necessário explicitar que as imagens eidéticas - as quais estabelecem as bases da atividade imaginária da criança pequena -, não se manifestam como reprodução exata/pura da realidade, mas já trazem implicadas a seleção e uma nova combinação de elementos dessa, gerando um processo peculiar de imitação, memorização e síntese.

Ao explorarmos a relação imaginação-linguagem-cognição-afeto, podemos compreender que, se o desenvolvimento da função imaginativa se ancora na elaboração conceitual, a formação de conceitos traz implicado o trabalho imaginativo, capaz de transformar os elementos que integram a realidade. A 


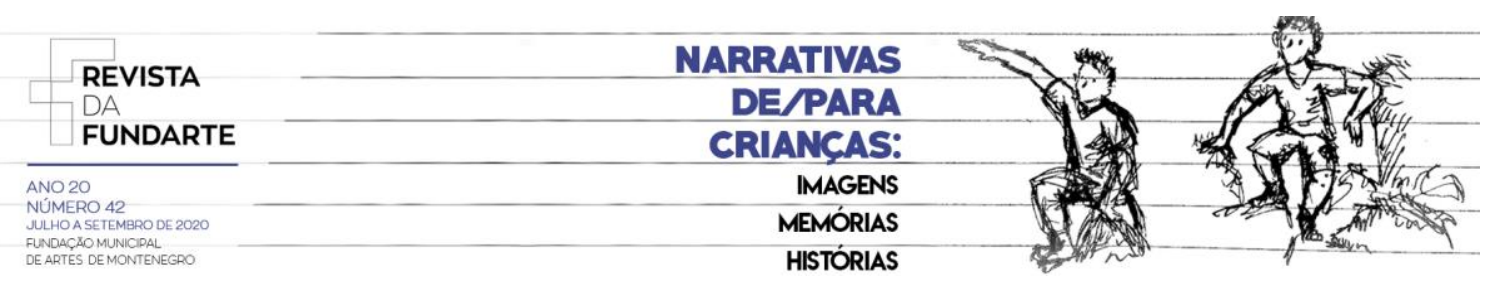

linguagem orienta o processo de percepção desta, possibilitando a generalização de imagens. Por sua vez, a imaginação coroa todas as funções psíquicas constitutivas da personalidade. Com efeito, o funcionamento psíquico se complexifica à medida que o desenvolvimento do pensamento conceitual se entrelaça à atividade criadora que carrega uma tonalidade emocional, desempenhando uma nova função na estrutura da personalidade.

Nessa concepção, a imaginação se apresenta como sistema psíquico de relações interfuncionais (VIGOTSKI, 1991, 1993), desdobrado da intensidade da vivência contraditória permeada de sentidos e afetos. Nas palavras de Petrovsky (2017, p. 186), a imaginação "é o reflexo da realidade em novas, inesperadas e não acostumadas combinações e conexões". Também encontramos em Tateo (2016) a definição de imaginação como um complexo semiótico em que se articula fantasia, memória, tomada de perspectiva, percepção, intersubjetividade e categorização. Já a criação consiste na objetivação da imaginação, ou seja, configura-se enquanto esfera de atividade humana, que possibilita a realidade ser narrada e transfigurada.

A criação do novo requer trabalho com imagens e sentidos, em que as imagens são apoiadas em palavras, em afetos, reunindo toda a profusão dos detalhes da concretude da vivência social e simbólica. Em outros termos, a atividade criadora depende das propriedades da situação concreta, das formas de mediação, dos processos simbólicos, intencionais, volitivos conquistados no processo de subjetivação, os quais libertam o sujeito das amarras do imediatismo, invocando espaços de ressignificação e objetivação de elementos culturais.

Coloca-se em pauta nessa discussão o problema da vontade, cuja orientação é coletivamente construída, configurando-se como função psíquica que executa e potencializa as demais. Nesse sentido, Vigotski $(1991,1993,1997)$ afirma que a atividade voluntária é mais importante do que um intelecto altamente desenvolvido. O seu papel no processo criativo deve ser compreendido no espaço-tempo de relações em que o sujeito se insere, considerando as motivações, interesses e necessidades, as condições subjetivas e objetivas do contexto (MOLON, 2007). 


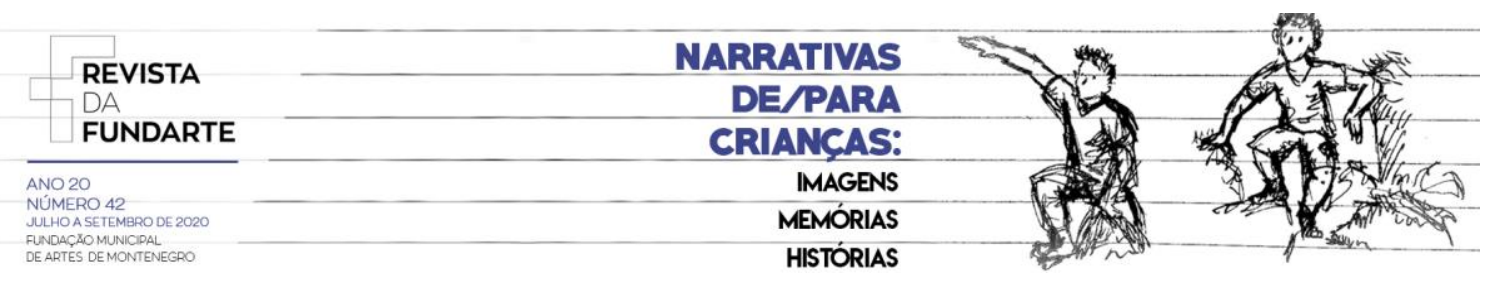

Dessa forma, o processo de apropriação carrega em si a atividade volitivacriativa, que dilata as vias de desenvolvimento cultural da pessoa. A criança, o adolescente ao se apropriarem dos artefatos técnico-simbólicos, para além de receberem e absorverem informações do ambiente, participam como autores da própria atividade, como sujeitos ativos, sensíveis e criativos, que significam e colaboram com a produção de cultura na relação mediada com o outro e com o objeto de fruição.

Sawyer (2012) discorre sobre os domínios criativos - sistemas simbólicos complexos que representam a história de produção humana - salientando a problemática acerca da separação dos processos de internalização e criação que têm atravessado os estudos contemporâneos. Contesta tendências que abordam a infância como momento de internalização e acumulação de elementos para a construção de uma base que gere a posteriori uma nova combinação criativa. A transformação é uma parte resultante da percepção, uma vez que essa envolve apreensão e combinações singulares de componentes do meio social.

Essa preocupação também é encontrada nos estudos de Rogoff $(1997,1998)$, para quem a criança e o meio social estão intrinsecamente ligados. A ocorrência do ato criativo só é possível dentro de um contexto social mediatizado e mediatizante, de tal modo que o processo é contínuo, fluido e as informações e os conhecimentos não atravessam uma fronteira concreta que separa o ambiente da criança.

Dessa maneira, a apropriação implica a construção criativa, em que a criança e o adolescente, enredados nas relações e modos de produção social transitam no plano da intersubjetividade. A imaginação criativa se mostra, assim, como uma das condições mais importantes para a apropriação da experiencia social do sujeito.

\section{Alguns elementos da História de Cristina}

A produção de imagens e textos, foco das análises do presente artigo, foi realizada semanalmente durante o segundo semestre de 2017 e o primeiro semestre de 2018 no contexto de aulas de Artes Visuais das quais participava uma professora 


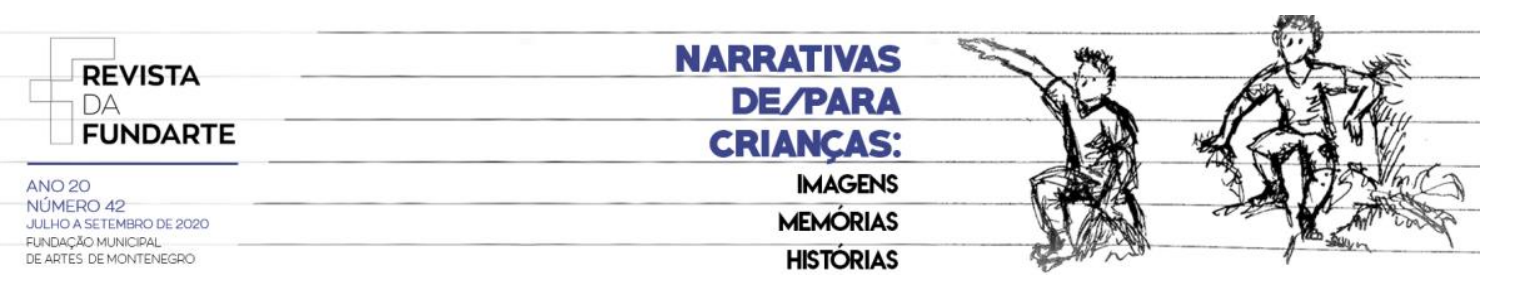

de Artes e uma adolescente com Transtorno do Espectro do Autismo (TEA), em um centro de reabilitação vinculado a uma universidade do interior do estado de São Paulo.

A jovem, que chamaremos de Cristina, (14 anos), vinha participando desde os 5 anos de idade de atendimentos terapêuticos naquele centro, em razão de demandas relacionadas ao desenvolvimento, à linguagem e a aprendizagem.

Desde cedo, a menina evidenciou grande interesse pelo desenho, em particular pela temática de animais. Sua facilidade no desenho chamou a atenção nos atendimentos, não somente pela discrepância com outros aspectos do seu desenvolvimento, mas também porque o estilo de representação não era típico em comparação às produções de outras crianças da mesma idade. Ela desenhava animais em movimento, produzia sequências narrativas em imagem, em claro diálogo com a imagética presente nos filmes de animação, por exemplo.

Como outras crianças cujas características são discutidas na literatura sobre o desenvolvimento do desenho na infância ${ }^{4}$, Cristina parecia deter na memória um amplo repertório figurativo e dominar códigos de representação espacial e figurativa incomuns para sua idade. Existe farta literatura sobre o desenho chamado de "extraordinário" de crianças "talentosas" e crianças com diagnóstico de TEA. Parte dessa literatura discute histórias individuais devido à singularidade de cada situação, enquanto outros estudos buscam investigar empiricamente as soluções para representação de figuras no espaço a partir de exercícios variados (REILY, 2001). No presente artigo centraremos a análise nos textos e desenhos produzidos por Cristina e sua professora a partir de uma proposta desenvolvida ao longo de vários encontros, com o objetivo de dar visibilidade à criação, ao desenvolvimento da imaginação e aos modos de apropriação do conhecimento e da cultura na perspectiva que destaca o papel do outro, da linguagem e do diálogo nesses processos.

Muitos relatos tendem a sugerir que os talentos artísticos de crianças com autismo brotam espontaneamente, sem estímulo ou suporte, como uma

\footnotetext{
${ }^{4}$ Ver Freeman; Cox (1985), Goodnow (1979); Golomb (1992).
}

REILY, Lucia Helena; LAPLAN, Adriana Lia Friszman de; DAINEZ, Débora. Texto e imagem em diálogo: modos de apropriação da cultura por uma jovem com transtorno do espectro do autismo Revista da FUNDARTE. Montenegro, p.01-32, ano 20, no 42, julho/setembro de 2020. 


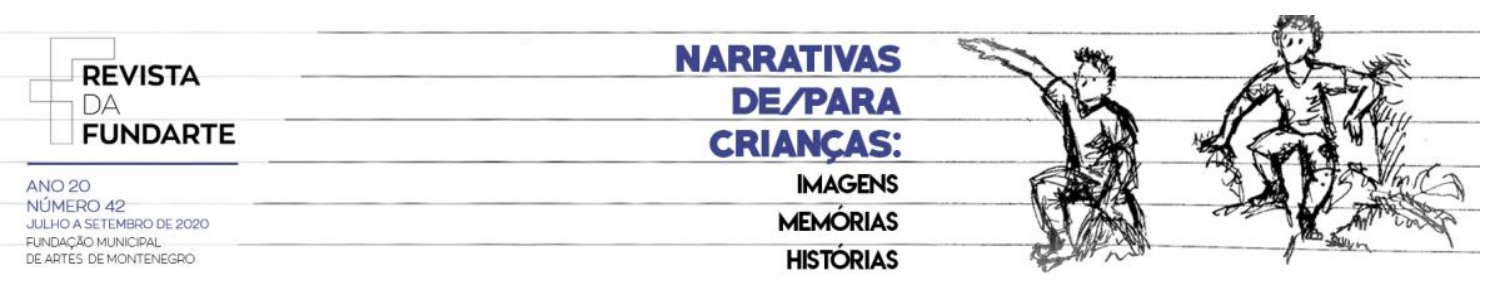

necessidade vital que demanda expressão, e que prescinde de ensino. No estudo de Reily (2001), porém, foi identificada uma interessante relação entre os desenhos e pinturas do participante de seu estudo e referências visuais da mídia, as quais se tornaram significativas e por isso foram colecionadas por ele. Assim também, constata-se que Cristina, filha de mãe e pai que atuam profissionalmente no campo de Artes Cênicas, teve e tem amplo acesso a variados tipos de bens culturais produzidos para crianças e adolescentes, como livros de histórias, gibis, programas de televisão, filmes e brinquedos e jogos. Nos relatórios do seu prontuário constam as propostas de atividades em que imagens eram utilizadas para incentivar a contação de histórias, o jogo simbólico e a escrita. Os registros dessas atividades estão repletos de evidências de manuseio de imagens e apropriação de segmentos de filmes pensados para o público infantil.

As aulas de Artes Visuais com Cristina começaram em março de 2014; às vezes, quando era possível formar um grupo ou dupla, o atendimento ocorria com outras crianças. Nosso objetivo era promover maior domínio da linguagem plástica, por meio de ampliação do repertório temático e interpretação de imagens. No início, seu repertório gráfico já era amplo, ainda que alguns animais, como os dinossauros, as hienas e os tigres fossem presenças especialmente constantes nos seus desenhos. O trabalho foi mudando quando Cristina entrou na adolescência: as propostas passaram a envolver trabalhos tridimensionais, animações, trabalhos com artes gráficas e com xilogravura. As técnicas oferecidas eram mais complexas e diversificadas.

Cristina frequenta atualmente uma escola estadual de ensino médio. À medida que as discrepâncias de desempenho entre Cristina e seus colegas na escola regular foram aumentando, seus pais procuraram um colégio em que as suas necessidades e potencialidades singulares fossem acolhidas. Em curto espaço de tempo, foram várias trocas de escola, na tentativa de achar um espaço inclusivo que promovesse sua aprendizagem e participação social. No contexto terapêutico, Cristina não aceitava falar de suas dificuldades na escola, mas sua conduta sugeria que as pressões acadêmicas lhe causavam sofrimento, tanto que qualquer atividade 


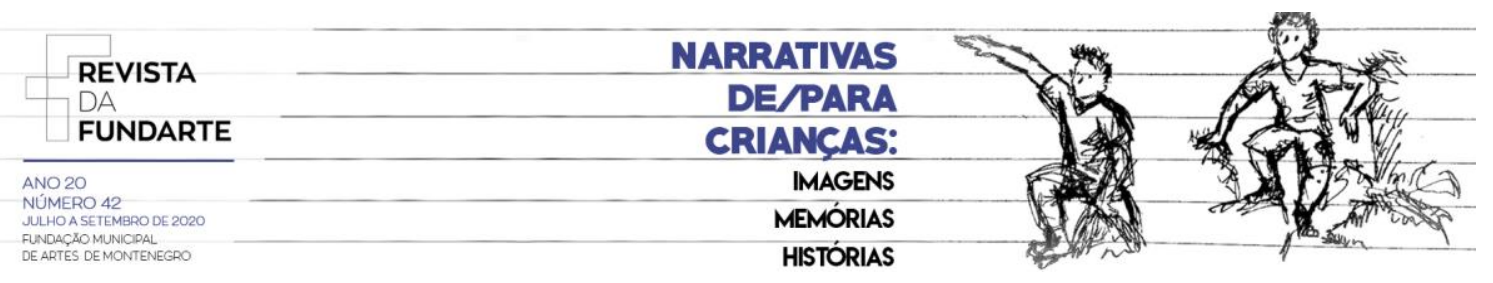

com teor escolar resultava em resistência e recusa. O trabalho com histórias desenhadas e escritas dialogadas, ao se distanciar do modelo escolar, promoveu a elaboração escrita numa situação altamente motivadora para a jovem.

Os trabalhos aqui analisados envolvem o origami ${ }^{5}$. A técnica requer que se siga uma sequência de passos delineados nas instruções para que o resultado se assemelhe a um modelo. Um dos objetivos das atividades era que Cristina aprendesse a interpretar as instruções visuais, para que ela pudesse realizar a dobradura em casa com maior autonomia. Conhecendo alguns esquemas de dobras, seria possível avançar para outras invencionices com papéis coloridos, sem restrição a modelos fixos. Obtivemos como doação um livro/manual primoroso de origami6 $^{6}$ com dezenas de figuras de animais, contendo também muitas folhas de imagens texturadas instigantes, com padrões coloridos variados. Este livro apresentava nas primeiras páginas um "modo de fazer", ou seja, um glossário imagético de dobras com seus respectivos códigos explicativos - algo que pretendia auxiliar o leitor a seguir a sequência de instruções visuais para confeccionar a figura escolhida. Cristina imediatamente se interessou pelo material e começamos a tentar interpretar as sequências de passos para realizar as dobras.

\section{A construção das histórias}

O primeiro momento era definido pela escolha de Cristina de qual animal ela queria aprender a fazer em origami. Cada participante escolhia uma folha colorida do livro, e em seguida era feita a dobradura, seguindo os desenhos instrucionais. Cristina pedia ajuda para as dobras difíceis e a professora também expressava sua frustração quando não conseguia entender como realizar as dobras indicadas nas instruções.

Cristina então realizava a colagem dos dois personagens numa folha colorida tamanho A3 de papel colorset de 120 gramas. Nesta etapa, o posicionamento dos

\footnotetext{
${ }^{5}$ Origami: técnica de dobradura em papel de origem japonês.

${ }^{6}$ O principal recurso utilizado foi o livro Origami World de Didier Boursin (2009), mas recorremos também a outros manuais.
}

REILY, Lucia Helena; LAPLAN, Adriana Lia Friszman de; DAINEZ, Débora. Texto e imagem em diálogo: modos de apropriação da cultura por uma jovem com transtorno do espectro do autismo Revista da FUNDARTE. Montenegro, p.01-32, ano 20, № 42, julho/setembro de 2020.

Disponível em: http://.seer.fundarte.rs.gov.br/index.php/RevistadaFundarte/index> 30 de setembro de 2020 


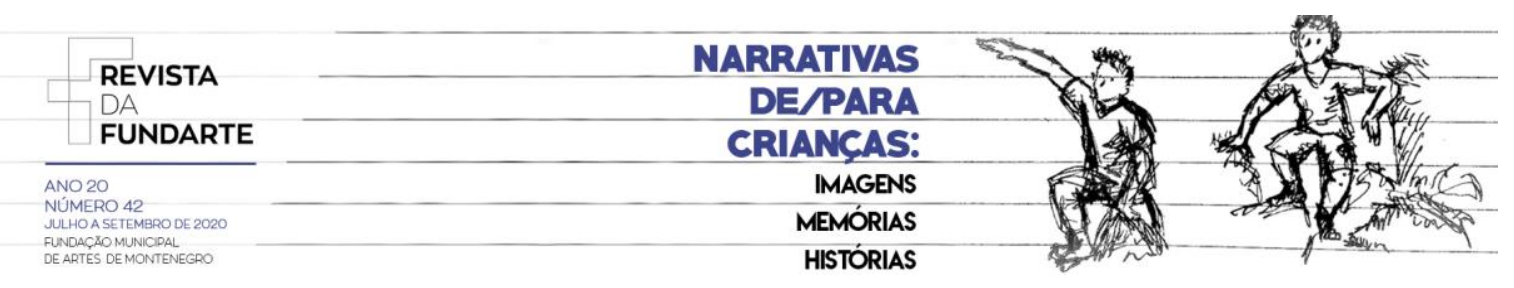

animais (frente a frente, lado a lado, um atrás do outro, por exemplo), de certa forma, já sugeria as possíveis relações entre os personagens, mas às vezes as definições apareciam na etapa de nomeação.

As relações entre os personagens eram definidas por Cristina antes da colagem das dobraduras; primeiramente a jovem e em seguida a professora escolhiam os nomes dos seus personagens. A professora escolhia nomes relacionados ora à textura do papel da dobradura, ora à sonoridade do nome que Cristina definira para batizar seu personagem.

O diálogo em texto se iniciava com as participantes alternando turnos. Durante o processo, a jovem olhava com expectativa para a professora, aguardando a reação quando suas linhas eram lidas em voz alta. Por sua vez, encorajava a professora, "Vai!" se ela demorasse um pouco enquanto pensava na continuidade da escrita. A colagem era complementada com canetinha hidrográfica ou lápis de cor, acrescentando outros elementos ou um desenho novo era produzido para ilustrar a história. Ao comentar esta nova representação, às vezes ocorria um equívoco de interpretação, levando Cristina a dar risada com o erro, que ela então nomeava corretamente.

\section{A história dos dinossauros Tino e Roxana}

Os dinossauros Tino (Cristina) e Roxana (a professora) são um casal de pais de quatro ovos; enquanto aguardam os filhotes saírem dos ovos, imaginam a cor e o sexo de cada um e planejam o que vão dar para eles de presente. As meninas vão ganhar biquíni e o presente dos meninos serão aviões de guerra e uma visita da família ao parque de diversões, onde os filhotes poderão ganhar brinquedos de pelúcia.

O encadeamento narrativo leva Cristina a desenhar a cena do nascimento dos filhotes de dinossauro, conforme o diálogo escrito. Tino (Cristina) e Roxana (a professora) levam na mão/pata os presentes que prometeram dar aos filhos, e os filhos são da cor que Tino propôs, sendo um míope como a professora: 


\begin{tabular}{|l} 
REVISTA \\
DA \\
FUNDARTE
\end{tabular}

TINO. Roxana esses ovos são bebês amor!

ROXANA. Mas Tino, eles parecem ovo de galinha.

T. E amor ovos so dinossauros ou comso amimais vivem aves.

R. Então vamos ganhar 4 filhotes?

T. Esta bem amor.

R. Você acha que eles vão ser azuis como você, vermelhos como eu, ou uma mistura de nós dois?

T. Meu amor filhotes poder os cores azuis, rosa, verde, e laranja só meninos e meninas.

R. Oba! Duas meninas. Vou comprar um biquíni de bolinhas para elas irem na piscina.

T. Bem! Dois meninos vou comprar brinquendo aviãos de guerra para eles e eles gosto dos parque dediversão

R. Amor, acho que eles vão gostar mais do pai do que da mãe porque parque de diversão é tudo de Bom!

T. Sim acho eles vai gostar do parque e tem jogos para ganhar brinquedo de pelúcia.

R. Quero ir junto! Que dia eles vão nascer? Tomara que seja amanhã.

T. Amor eu acho eles nascer a amanhã, e dez minutos!

R. Nasceram! Que lindos! Um azul, um verde, um rosa e um laranja de óculos! Parabéns Papai!!

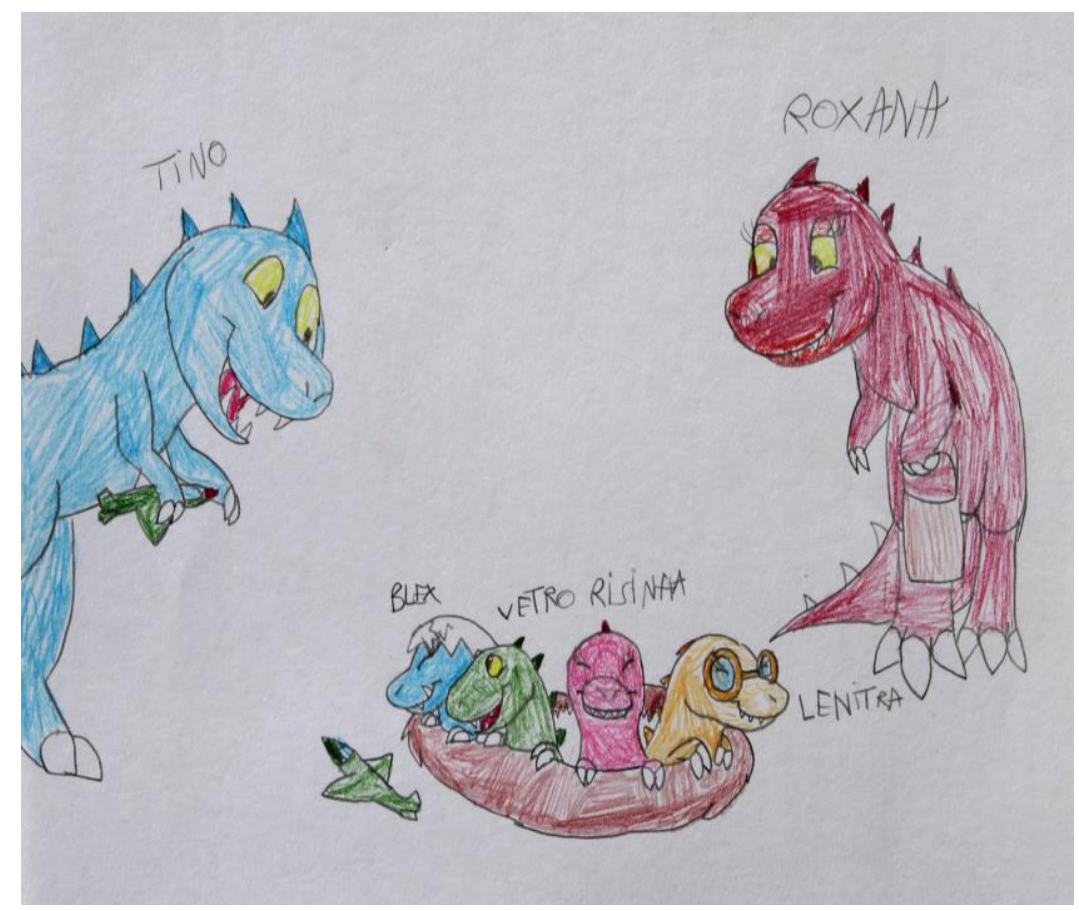

Ilustração 1: Tino e Roxana e seus quatro filhotes. Desenho de Cristina. (Fonte: Foto de Arq. LHR)

REILY, Lucia Helena; LAPLAN, Adriana Lia Friszman de; DAINEZ, Débora. Texto e imagem em diálogo: modos de apropriação da cultura por uma jovem com transtorno do espectro do autismo Revista da FUNDARTE. Montenegro, p.01-32, ano 20, no 42, julho/setembro de 2020.

Disponível em: http://.seer.fundarte.rs.gov.br/index.php/RevistadaFundarte/index> 30 de setembro de 2020 


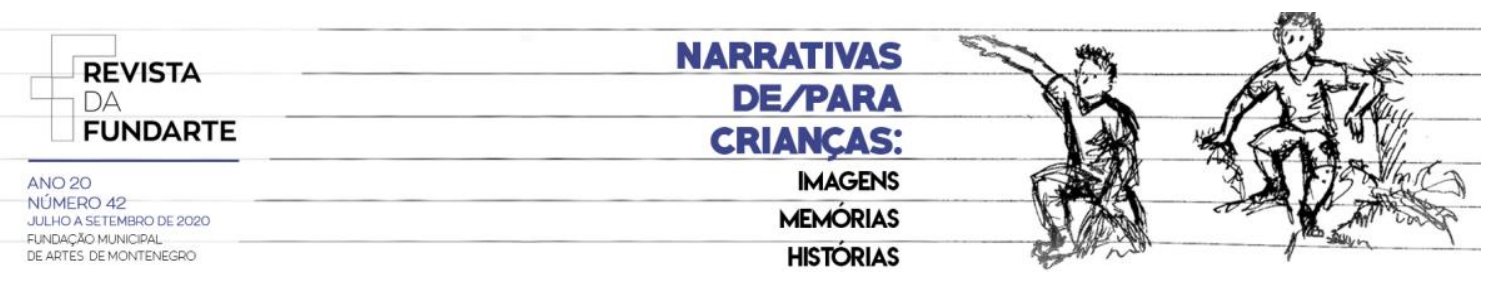

Destacamos o processo de construção conjunta da narrativa. A jovem inicia o diálogo, comentando sobre os ovos, dos quais viriam os bebês dinossauros. $\mathrm{Na}$ dinâmica narrativa, assume o lugar de autora e de personagem, participa da criação do enredo e encena a história. Acolhe e incorpora elementos enunciados pelo interlocutor e introduz novos elementos.

A professora intervém no diálogo de forma a subsidiar a emergência de novas associações na composição da trama. Diante da provocação em relação à aparência dos ovos (que parecem de galinha), Cristina explica que os dinossauros são como as aves, botam ovos. O conhecimento prévio que a jovem detém sobre a classe dos animais ovíparos é mobilizado e incorporado no fluxo da construção narrativa, possibilitando a réplica ao interlocutor. A professora indaga sobre a cor e a aparência dos filhotes, o que leva Cristina a associar as cores dos bebês ao gênero (dois filhotes dinossauros do gênero masculino nas cores azul e verde, e duas filhotes dinossauros do gênero feminino nas cores rosa e laranja). A professora introduz no texto um novo elemento, a filhote dinossauro laranja usa óculos, assim como ela própria e também Cristina. No desenho complementar à colagem, Cristina insere este detalhe que aparece na última linha da história e revela sua atenção a tudo que compõe a narrativa.

A interação, entretanto, é complexa: algumas das iniciativas da professora não provocam a continuidade do diálogo e Cristina rapidamente conclui o tópico (quando a professora pergunta sobre o número de filhotes, Cristina responde apenas: "está bem, amor").

O texto narrativo produzido pela jovem no contexto de criação/encenação da história, assim como a representação do desenho são permeados pelas percepções sociais e conhecimentos sobre a configuração e as relações familiares - os papéis assumidos pelo pai e pela mãe -, o evento do nascimento, os atributos dos gêneros.

No que se refere à confecção da dobradura, o posicionamento, a direção e a forma de destacar as asas, olhos, rabo, pé, focinho, etc. mostram a compreensão da representação típica da técnica de dobradura japonesa e da sua particular estilização. Cristina é competente na identificação dessas formas estilizadas, que 


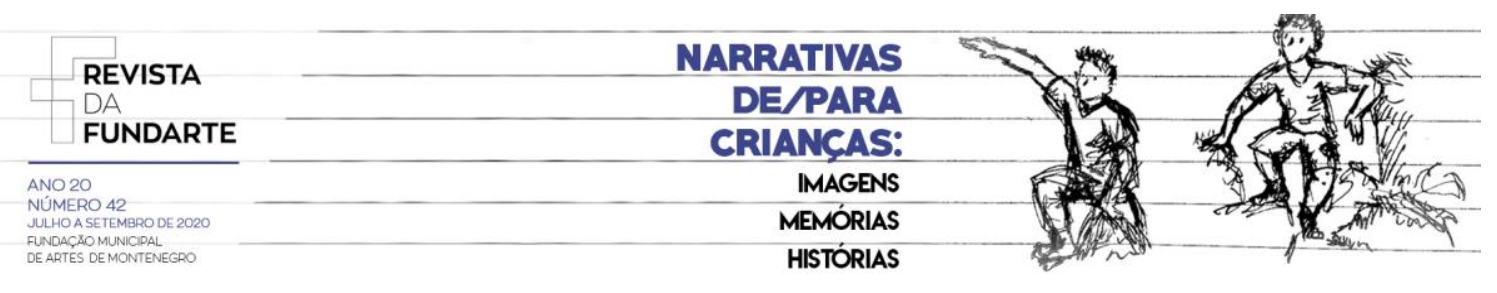

implicam um alto grau de abstração, com os animais representados. Também evidencia o seu conhecimento do ambiente onde viviam os dinossauros. Depois de colar os dois dinossauros em origami frente a frente na região central de folha, ela criou um espaço a lápis com lago no primeiro plano, onde um peixe dá um salto, com coqueiros e arbustos ao fundo, atrás dos dinossauros. Entre os dois animais, e sob seu olhar conjunto há um ninho com quatro ovos, detalhe que provoca todo o encadeamento narrativo.

No seu desenho complementar posterior à escrita partilhada, Cristina revela seu domínio representacional. Ela inclui na cena os presentes prometidos: Roxana leva uma sacola que contém os biquínis e Tino segura um avião de guerra. Tino, à esquerda na folha, sangra a borda, ou seja, apenas a parte frontal do corpo aparece, enquanto Roxana está representada integralmente. Os filhotes são mostrados dentro do ninho em semicírculo, virados para fora: os dois machos (Blex e Vetro) em perfil à esquerda, a fêmea rosa (Risinha) frontalmente e a sua irmã laranja (Lenitra) em posição três quartos, virada para a mãe. As patas dos quatro filhotes acompanham respectivamente a posição de cada um, algo que demanda domínio de desenho em escorço. Cabe ainda salientar que o olhar dos dinossauros, definido pelas pupilas ressalta o foco conjunto de Tino e Roxana para os filhotes, enquanto Vetro volta seu olhar acima para o pai. Todas as fêmeas têm cílios, mas os machos não. Como é frequente em ilustrações de produção cultural para crianças, Blex tem na cabeça, como um capacete, a sobra da casca do seu ovo. Mesmo com dentes afiados, garras e escamas dorsais, a expressão facial sorridente e antropomórfica dos dinossauros não sugere perigo.

O movimento de imagens e sentidos é, assim, ancorado no plano da vivência social do sujeito. O processo de imaginação criativa se torna possível, a partir do trabalho com os elementos afetivos, cognitivos, interativos presentes no meio em que a jovem se insere e participa. 


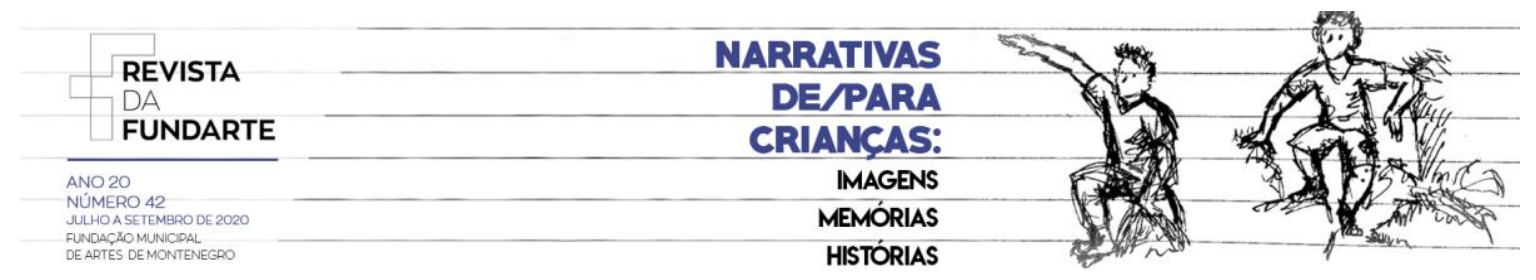

\section{A história dos pintinhos Raiana e Arenoso}

Os pintinhos Raiana (Cristina) e Arenoso (a professora) eram irmãos. O diálogo acontece no seu primeiro dia de vida. Arenoso machucou o bico ao sair da casca e Raiana propõe colocar um bandaid. A mãe vem e pergunta o que querem comer. Enquanto ela providencia a comida, os pintinhos planejam os desenhos que querem assistir na televisão com seus amigos. A mãe faz pipoca e o pai chega trazendo os amigos, que são outros animais da fazenda.

RAIANA. Que dia legal, né Arenoso.

ARENOSO. Sim! É o primeiro dia das nossas vidas. Meu bico ainda está doendo. E o seu? (Arenoso indica com essa fala que para sair do ovo foi preciso bicar a casca).

R. Não, o seu bico tá doendo, eu vou buscar uma coisa tá.

A. Qual é a coisa que você vai buscar? Estou curioso!

R. Caixa do médico eu vou buscar tá já volto.

A. Você vai pôr uma pomada ou um bandaid?

R. Bandaid.

A. Xi! Mas daí meu bico vai ficar grudado. Como faço para comer as minhocas no almoço?

R. Você pode comer a sopa de minhocas. Eu vou fala minha mãe ela vai fazer a sopa, certo.

A. Ótima ideia. Vamos chamar a mamãe! Mamããããe!

Ela nem viu que nós nascemos!

MAMÃE. Vi sim filho que você quer? Quer uma coisa pra comer?

A. Mamãe, a Raiana e eu queremos 3 coisas: Sopa de minhoca, suco de milho e...

R. Salada de tomate.

(Enquanto a mãe vai providenciar a comida os pintinhos resolvem assistir filmes.)

A. Raiana, vamos assistir televisão enquanto a mamãe não chega?

R. Sim Arenoso ela volta é o sol vai embora chega pra minha casa, claro vamos assistir televisão é qual você quer asstir?

A. Vamos assistir desenho do Pato Donald? Você gosta de qual filme? "A fuga das galinhas" ou qual?

R. Sim, eu gosto "A fuga das Galinhas" e Pato Donald, bem vou o filme é "Os Segredos dos Animais" você gosto?

REILY, Lucia Helena; LAPLAN, Adriana Lia Friszman de; DAINEZ, Débora. Texto e imagem em diálogo: modos de apropriação da cultura por uma jovem com transtorno do espectro do autismo Revista da FUNDARTE. Montenegro, p.01-32, ano 20, no 42, julho/setembro de 2020.

Disponível em: http://.seer.fundarte.rs.gov.br/index.php/RevistadaFundarte/index> 30 de setembro de 2020 


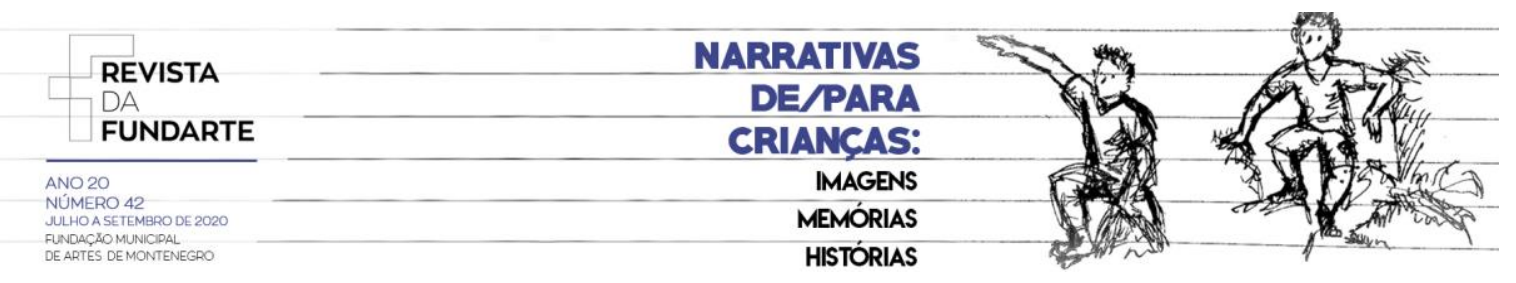

A. Raiana, eu não conheço "Os Segredos dos Animais." Sobre o que é o desenho?

R. O "Segredo dos Animais" são a fazenda só desenho a vaca cuida todos a fazenda. O segredo é: casa da fazenda a noite pra festa.

A. Vamos fazer pipoca pra comer enquanto a gente vê o filme? Como a mamãe vai trazer milho, podemos fazer pipoca. Você sabe fazer?

R. Ah, sim.

M. Crianças cheguei, trouxe as minhocas vou guardado amario da cozinha e tomate vou guarda na geladeira, ah eu trouxe os milhos vou fazer a pipoca e o suco de milho.
A. Eba!
R. Oba!

(Os pintinhos convidam os amigos para assistir o filme e comer pipoca).

A. Raiana, que amigos temos aqui?

$\mathrm{R}$. Eu vou convidar meus amigos e a minha amiga: ganso, porquinho, ratinho e minha amiga e esquila.

A. Meus amigos e minha amiga são: patinho, cisne, gatinho e a ovelha.

PAI. Oi crianças eu trouxe seus amigos e suas amigas vamos pra assistir os desenhos.
A. EBA!
R. É!

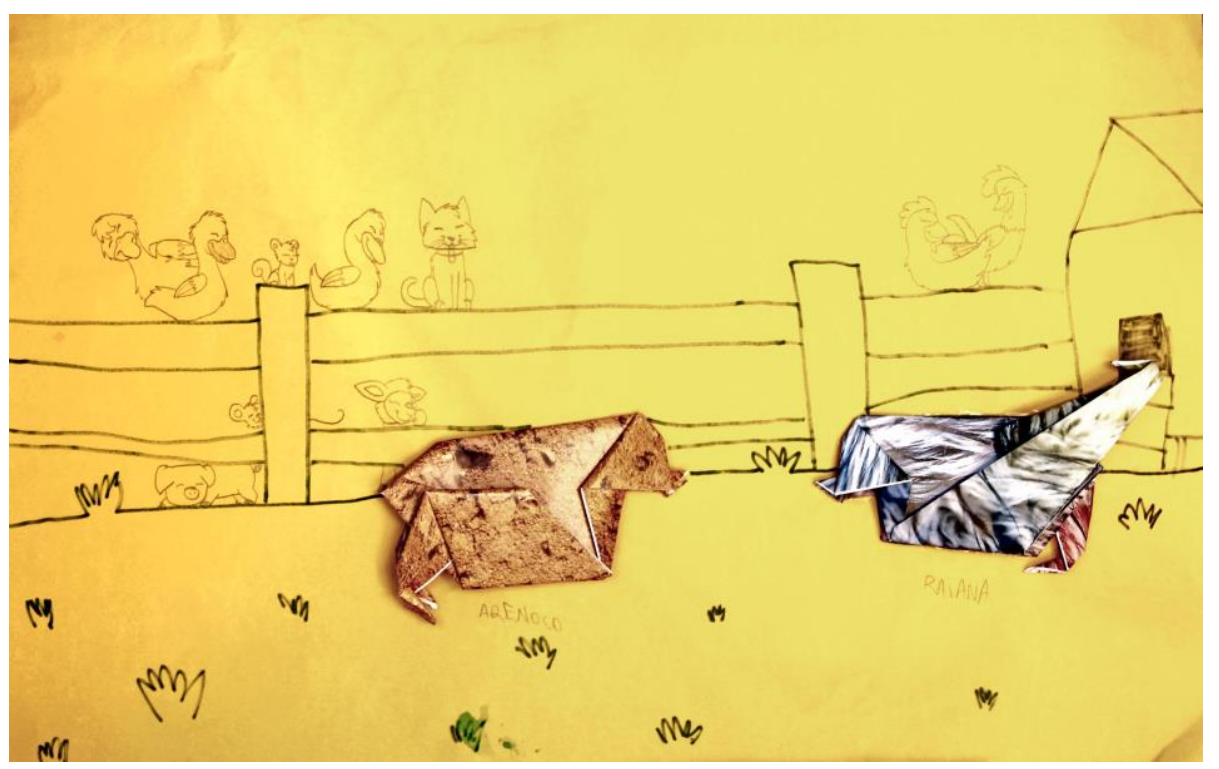

Ilustração 2. Colagem dos pintinhos Arenoso e Raiana com amigos desenhados a lápis preto.

Desenho de Cristina. (Fonte: Foto de Arq. LHR)

REILY, Lucia Helena; LAPLAN, Adriana Lia Friszman de; DAINEZ, Débora. Texto e imagem em diálogo: modos de apropriação da cultura por uma jovem com transtorno do espectro do autismo Revista da FUNDARTE. Montenegro, p.01-32, ano 20, no 42, julho/setembro de 2020.

Disponível em: http://.seer.fundarte.rs.gov.br/index.php/RevistadaFundarte/index> 30 de setembro de 2020 


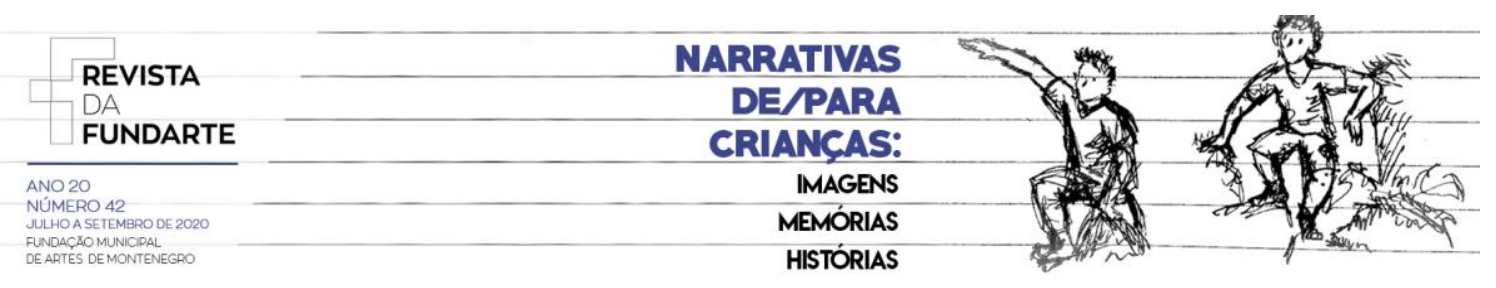

Neste processo narrativo, Cristina retoma a colagem dos pintinhos em origami para adicionar os amigos de Arenoso e Raiana. Ela havia situado os pintinhos no primeiro plano, diante de uma cerca de madeira que sangra a folha do lado esquerdo, enquanto ao lado direito consta o galinheiro com rampa de madeira com ripas para facilitar a subida das aves. A casinha também sangra a borda da folha, e este recurso gera a ideia de continuidade do espaço e da narrativa. Em poucos minutos ela desenhou todos os bichos a lápis sem necessidade de recorrer a nenhuma referência imagética. Os galináceos mãe e pai foram desenhados próximos à sua casinha; a galinha está na frente do galo e ambos viram as cabeças em direção um ao outro. Os animais amigos foram todos desenhados atrás de Arenoso, emoldurados pela cerca. Cristina localizou os animais de acordo com a sua compreensão sobre a capacidade que cada um tem para escalar a cerca. Esquila, gato, pato, cisne e ganso estão no sarrafo superior, enquanto a ovelha, o porco e o ratinho estão abaixo. A cerca de madeira é chapada, sem sugestão de perspectiva, mas Cristina demonstra seu domínio de oclusão de figuras atrás de outros elementos, com o rato e a ovelha atrás da cerca, e o ganso atrás do pato. Quando a professora perguntou sobre a televisão onde todos assistiriam ao filme, Cristina explicou que a tevê ficava dentro da casa.

No texto, Cristina toma a inicia o diálogo narrativo, desenvolve possibilidades de desfecho das situações e encadeia soluções coerentes relacionadas ao enunciado do interlocutor, muitas vezes, partindo para novos caminhos de continuidade da história. Também demonstra o domínio de fechar as narrativas com coesão, retomando o tópico anterior (por exemplo, no turno em que a mãe retorna das compras e avisa que trouxe os ingredientes para preparar a comida para os filhotes).

O seu dizer é sempre endereçado ao interlocutor. Observa-se a participação situada da menina na conversação; ela considera e retoma o discurso do outro na forma de "resposta" ao diálogo. Ou melhor, atua de maneira ativa e responsiva no espaço de criação conjunta (BAKHTIN, 2006). 


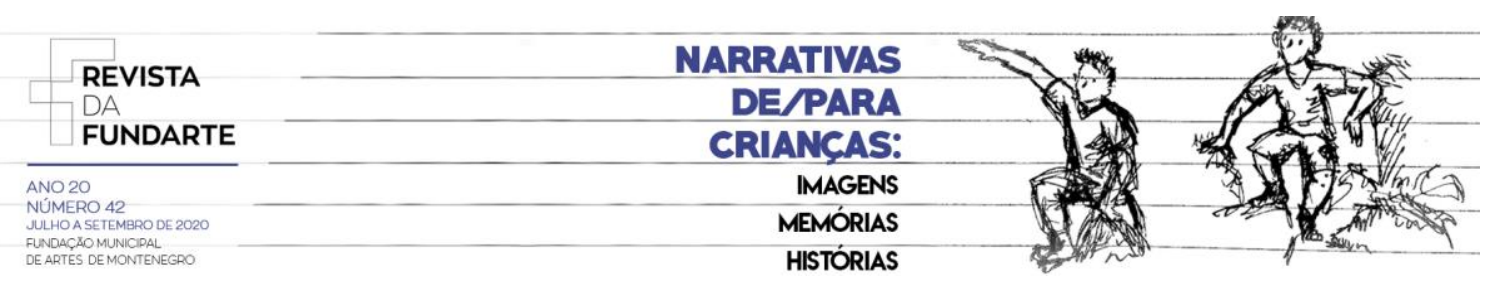

Os personagens assumidos pela jovem se mostram sempre muito disponíveis e positivos, preocupados com o outro e solícitos, dispostos a ajudar e a cuidar. De forma a lidar com a dor no bico de Arenoso, Raiana se prontifica a buscar a caixa do médico e escolhe usar um bandaid. Frente à dificuldade de Arenoso em comer as minhocas no almoço, Raiana pede que a mãe prepare uma sopa de minhocas. Quando Arenoso comenta sobre a desatenção e o desapego da mãe em relação nascimento - "Ela (a mãe) nem viu que nós nascemos!" -, Cristina reage e assume o papel de mãe, que contesta a percepção do filho e demonstra carinho, preocupação e cuidado (a mãe pergunta o que querem comer, sai em busca dos alimentos, retorna trazendo todos os ingredientes que lhe foram pedidos e prepara a refeição). Ao planejar uma situação de diversão, a garota assume o papel de pai, que vai buscar os amigos e amigas.

A sua narrativa expressa empatia social, cuidado com o outro, compreensão de como se estabelecem as relações interpessoais, familiares e de amizade, percepção dos papéis desempenhados pela mãe, pelo pai, pelos irmãos, pelos amigos. Apesar de que na vida cotidiana, Cristina encontra dificuldades em fazer amigos, os personagens que ela assume e os que ela representa, tanto no texto quanto no desenho, demonstram afeto e participam de práticas de socialização corriqueiras.

Cristina detém conhecimentos sobre filmes e desenhos para crianças relacionados à temática "animais da fazenda" e apresenta familiaridade com recursos utilizados no cinema. Trata-se de produções infantis pautadas em situações desafiadoras e busca de resolução de problemas de forma cooperativa. No filme "O segredo dos animais", referido por ela, aparecem elementos como: a vaca que cuida de todos na fazenda, a organização de uma festa pela noite. No processo de criação/encenação, Cristina incorpora esses elementos no manejo da narrativa.

Ao participar da criação de cenas imaginárias, Cristina entra no jogo de faz de conta e se faz protagonista, usa recursos textuais e imagéticos, mobiliza conhecimentos prévios, assume diferentes papéis. A fusão entre realidade e 


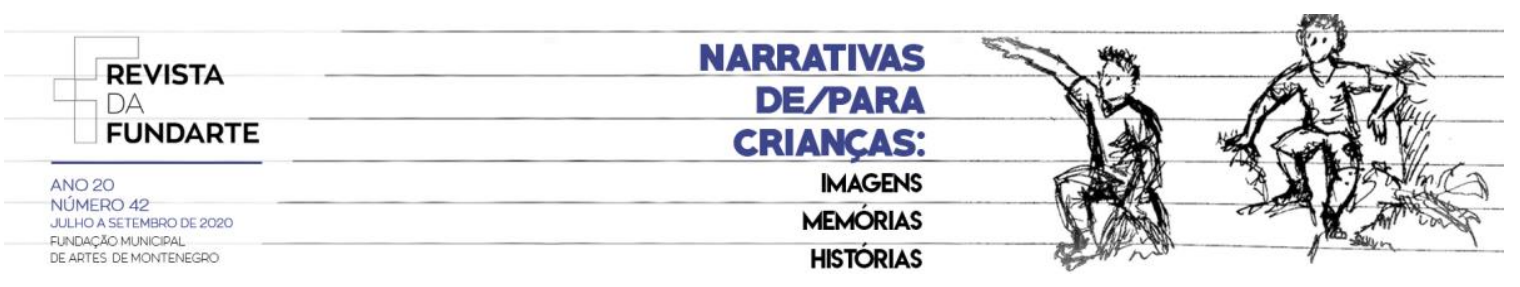

fantasia, com base nos filmes/desenhos infantis e nos artefatos presentes no meio em que vive, reflete o lugar da vivência social como condição para a criação imaginária.

\section{A história das corujas Osnlena e Suelen}

As corujas Osnlena (Cristina) e Suelen (a professora) eram duas amigas que vão caçar ratos à noite para fazer um caldo. Depois de uma discussão sobre a melhor maneira de caçar os ratos, Suelen avisa que não enxerga muito bem e propõe o uso de uma lanterna - ideia que Osnlena contesta por não ser possível para as corujas. Suelen então propõe pedir um colírio para o médico; assim se resolve o problema e podem então preparar a sopa de ratos.

SUELEN. Boa noite, Osnlena. Durma bem.

OSNLENA. Boa noite, Suelen

(Percebendo que Cristina não pegou a pista sobre o fato que corujas caçam à noite, a professora esclareceu:)

S. Eu estava só brincando. Porque coruja não dorme de noite.

O. Suelen coruja tabalho noite e durma no dia.

S. Isso mesmo. O meu trabalho é caçar. E você?

O. E também trabalho caçar com ratos.

S. Você caça os ratos com ratoeira ou com espingarda, Osnlena?

O. Corujas não pega ratoeira isso saber dor os ratos la vivem a casa e na floresta.

S. Entendi. Então você caça com as asas?

O. Sim Suelen minhas asas pode voar? E você também pode voar coruja pra comida dos ratos em!

S. Osnlena, de noite eu não enxergo muito bem, para caçar. Você tem uma lanterna para eu usar?

O. Não Suelen lanternas não usar no noite, eu enxergo meus olhos para ver tem, ratos coruja vai fazer!

S. Entendi. Então vou no médico para pegar um colírio para enxergar os ratos. Já estou com fome. Vamos fazer uma sopa de ratos?

O. Bem! Vamos fazer!

REILY, Lucia Helena; LAPLAN, Adriana Lia Friszman de; DAINEZ, Débora. Texto e imagem em diálogo: modos de apropriação da cultura por uma jovem com transtorno do espectro do autismo Revista da FUNDARTE. Montenegro, p.01-32, ano 20, № 42, julho/setembro de 2020.

Disponível em: http://.seer.fundarte.rs.gov.br/index.php/RevistadaFundarte/index> 30 de setembro de 2020 

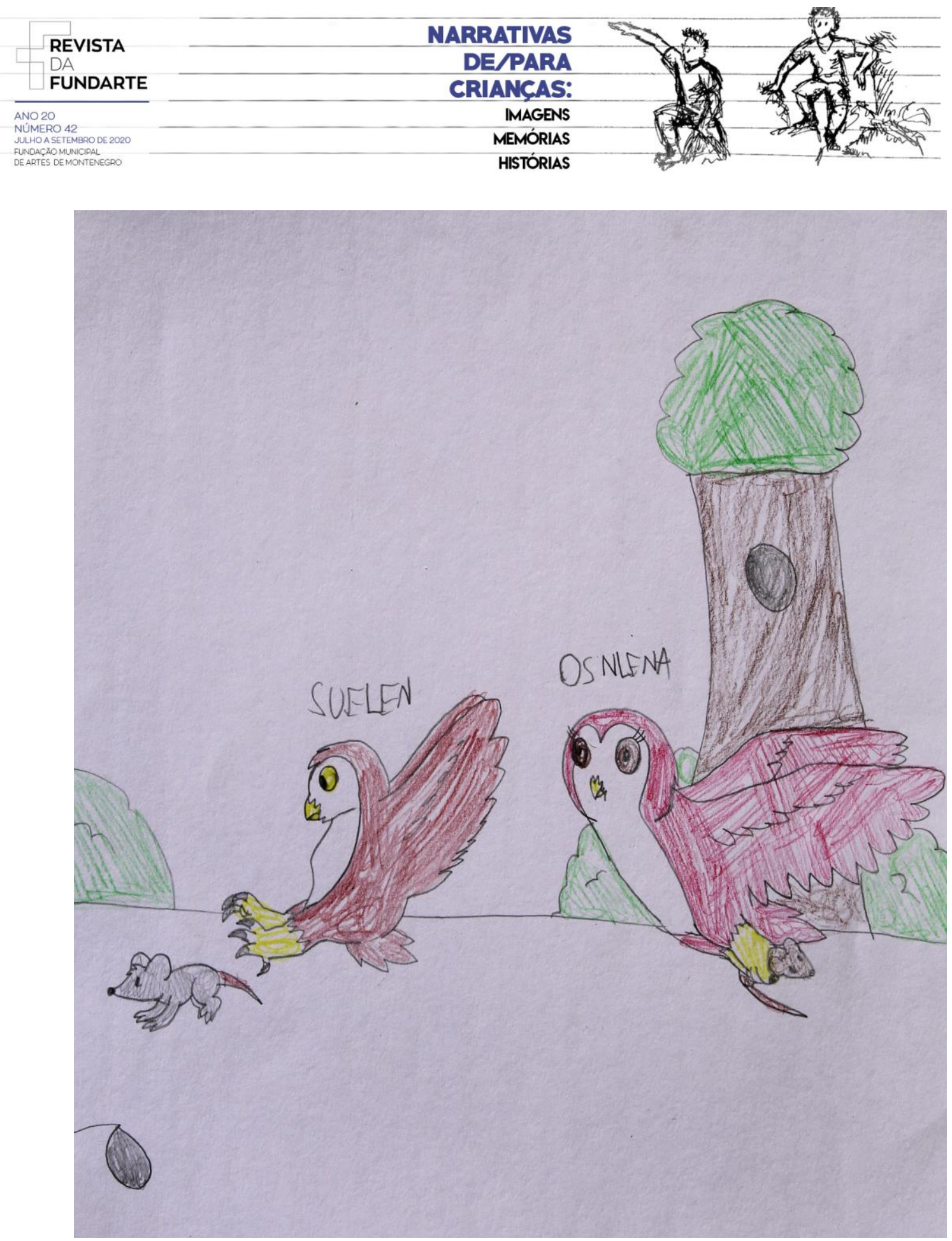

llustração 3. Desenho a lápis preto e lápis de cor das corujas Suelen e Osnlena caçando ratos.

Desenho de Cristina. (Fonte: Foto Arq. LHR)

REILY, Lucia Helena; LAPLAN, Adriana Lia Friszman de; DAINEZ, Débora. Texto e imagem em diálogo: modos de apropriação da cultura por uma jovem com transtorno do espectro do autismo Revista da FUNDARTE. Montenegro, p.01-32, ano 20, no 42, julho/setembro de 2020.

Disponível em: http://.seer.fundarte.rs.gov.br/index.php/RevistadaFundarte/index> 30 de setembro de 2020 

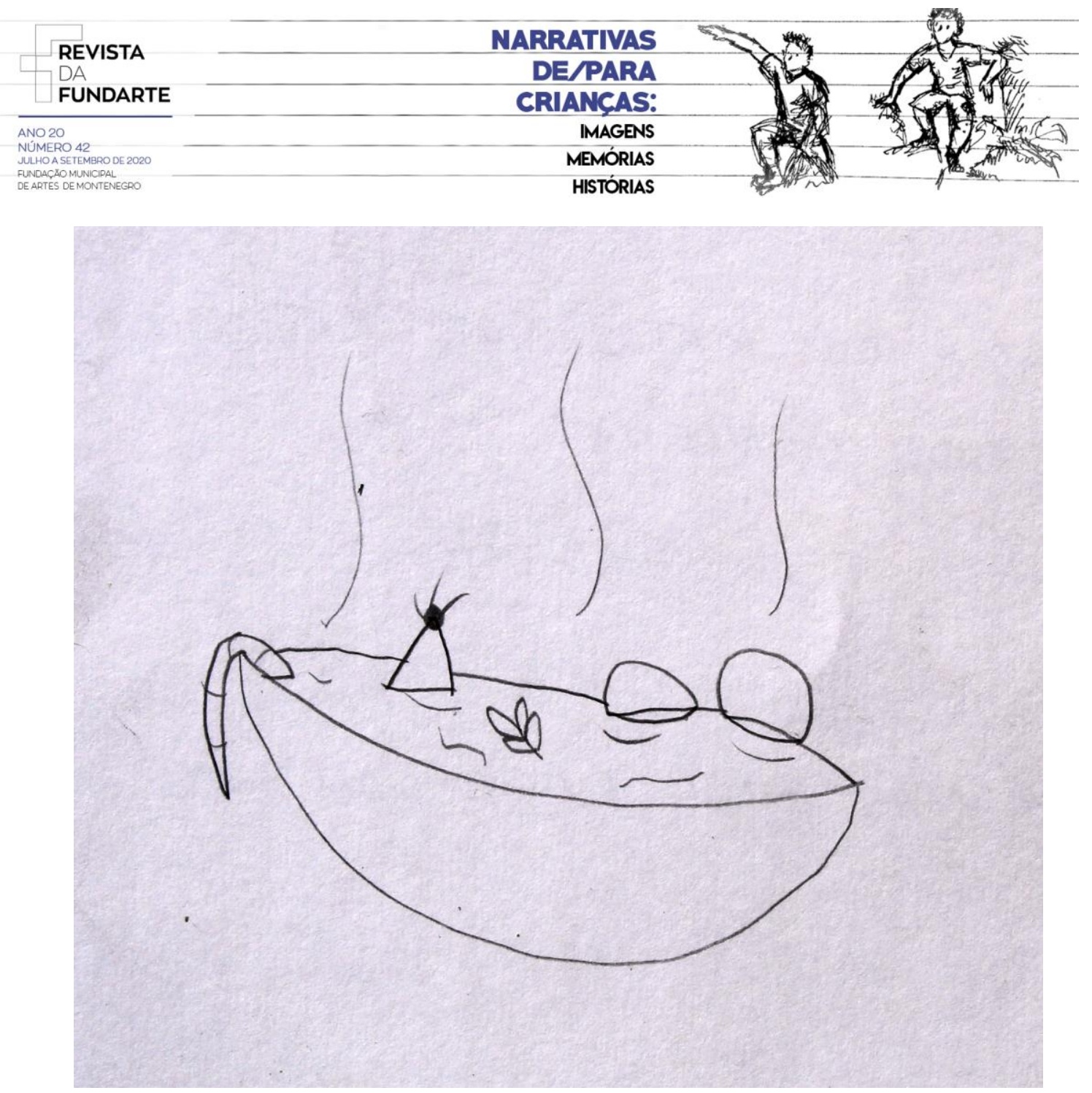

Ilustração 4. Desenho a lápis preto da sopa de ratos. Desenho de Cristina (Fonte: Foto Arq. LHR)

Na dobradura, Cristina posicionou ambas as corujas sobre um grosso galho horizontal à esquerda na folha, usando como suporte um fundo $\mathrm{roxo}^{7}$, que, juntamente com uma lua minguante no canto superior direito, designam a noite. Desenhou o fundo com lápis de cor branca. Nesse trabalho evidenciou seu domínio de composição, pois a árvore das corujas sangra a borda esquerda, mas ela buscou (intuitivamente) equilíbrio com os detalhes à direita. Escondidos atrás de uma pedra, num buraco numa árvore ao fundo e no galho de uma árvore vislumbram-se os ratinhos que antecipam o que vai acontecer na história.

Terminado o texto conjunto, Cristina produziu um desenho em lápis de cor, da caça, com as corujas em voo. Suelen é representada com as garras à mostra no

7 Devido à leveza do traço, optamos por não reproduzir esta imagem.

REILY, Lucia Helena; LAPLAN, Adriana Lia Friszman de; DAINEZ, Débora. Texto e imagem em diálogo: modos de apropriação da cultura por uma jovem com transtorno do espectro do autismo Revista da FUNDARTE. Montenegro, p.01-32, ano 20, № 42, julho/setembro de 2020.

Disponível em: http://.seer.fundarte.rs.gov.br/index.php/RevistadaFundarte/index> 30 de setembro de 2020 


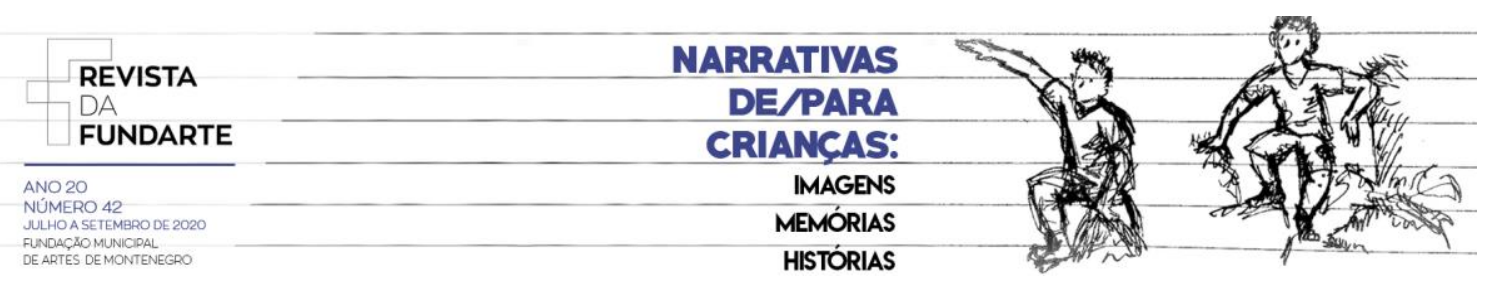

instante anterior ao de alcançar o ratinho que tenta inutilmente escapar. Osnlena voa atrás, segurando o seu ratinho desconsolado firmemente nas patas. Seguindo a sugestão da professora, na base da página de texto, Cristina desenhou a sopa de ratos, sem esboçar um sorriso, mas provocando muita diversão para a professora. $\mathrm{Na}$ tigela fumegante de sopa notam-se um rabo, orelhas e um focinho, bem como um ramo de ervas que serve de tempero.

No texto, a linguagem organiza o pensamento, mesmo quando não há um domínio completo da sintaxe convencional. O diálogo é iniciado pela professora. Ela faz uma provocação inusitada que Cristina parece não entender. A professora esclarece que as corujas têm hábitos noturnos é Cristina, então, incorpora os elementos: "corujas", "caçar", "ratos" e "noite", acrescentando ainda o elemento "trabalho", que é retomado nos turnos seguintes por ambas as participantes. Interessa destacar, aqui, a referência à dor que os ratos poderiam sentir se fossem caçados com ratoeiras. Esse argumento define a opção por "caçar com as asas". O tratamento da questão indica a elaboração da empatia e da compaixão em relação a outros seres vivos.

Cristina utiliza estratégias típicas de uma conversação: ela inicia ou conclui o diálogo, se apropria de fragmentos da fala da professora para transformá-los e fazer com que a narrativa evolua, contribuindo, ainda, com elementos próprios e usa fórmulas e formatos presentes em histórias infantis e, principalmente, nos filmes, que ela assiste frequentemente.

\section{A história dos gatos Icela e Brasa}

Um dos primeiros diálogos aconteceu entre os gatos Icela (Cristina) e Brasa (a professora), que eram amigos. Brasa queria se refrescar com um abraço de Icela, mas se isso acontecesse, ela derreteria. Resolveram o problema com a água do aquário do peixe Félix, colocando o Félix temporariamente num copo d’água.

BRASA. Oi Icela. Você está com frio hoje?

ICELA. Sim Brasa hoje com frio das neves, e você está com quente e hoje também?

REILY, Lucia Helena; LAPLAN, Adriana Lia Friszman de; DAINEZ, Débora. Texto e imagem em diálogo: modos de apropriação da cultura por uma jovem com transtorno do espectro do autismo Revista da FUNDARTE. Montenegro, p.01-32, ano 20, № 42, julho/setembro de 2020. 


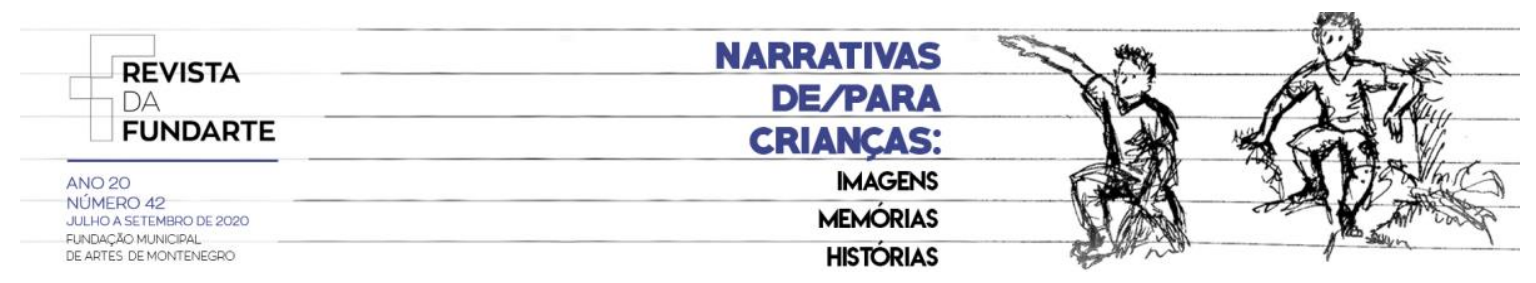

B. Icela, eu sempre sinto calor, não sei por que!

I. Por que, calor ta quente e fogos, sei bom sabe são gelos por que tã com frios mas se sabe são fogos porque tá com calor bem, quente sempre.

B. Icela, se você me der um abraço você pode me refrescar. Pode ser?

I. Verdade, se eu abraçar você mas. Pode ficar juntas, gelo vai derreter por que fogo, pode derreter dos gelos certo Brasa?

B. Certíssimo. Não quero que você vire uma poça d'água. Então tive uma ideia: jogue a água do aquário em mim para me refrescar.

I. Boa ideia Brasa você vai pegar aquário, mas por que uma água pode jogar mim, então eu vou refrescar pode abraça com você ta bem Brasa.

B. Só que tem um detalhe, Icela. Onde vamos colocar o Peixe Felix?

I. A e então vou pegar o copo, você pega o Peixe Felix e so que peixes entra no copo da água entendeu.

B. Entendi sim, Icela. Mas cuidado para não tomar água no copo e beber o Félix sem querer.

I. Tá bem Brasa não vou beber nenhum, pega o copo mas cuidado se você vai pega o aquário poder água quente o peixe Felix calor a Brasa colocar luvas não ter quente no aquário ta bem.

B. Ótima ideia. Pronto, coloquei luvas. Guardei o Félix no copo. Joga a água do aquário em mim e estou pronto para o nosso abraço.

I. EEE. Eu estão refrescar, pode abraços fogo e gelo nosso junto sempre.

REILY, Lucia Helena; LAPLAN, Adriana Lia Friszman de; DAINEZ, Débora. Texto e imagem em diálogo: modos de apropriação da cultura por uma jovem com transtorno do espectro do autismo Revista da FUNDARTE. Montenegro, p.01-32, ano 20, no 42, julho/setembro de 2020.

Disponível em: http://.seer.fundarte.rs.gov.br/index.php/RevistadaFundarte/index> 30 de setembro de 2020 


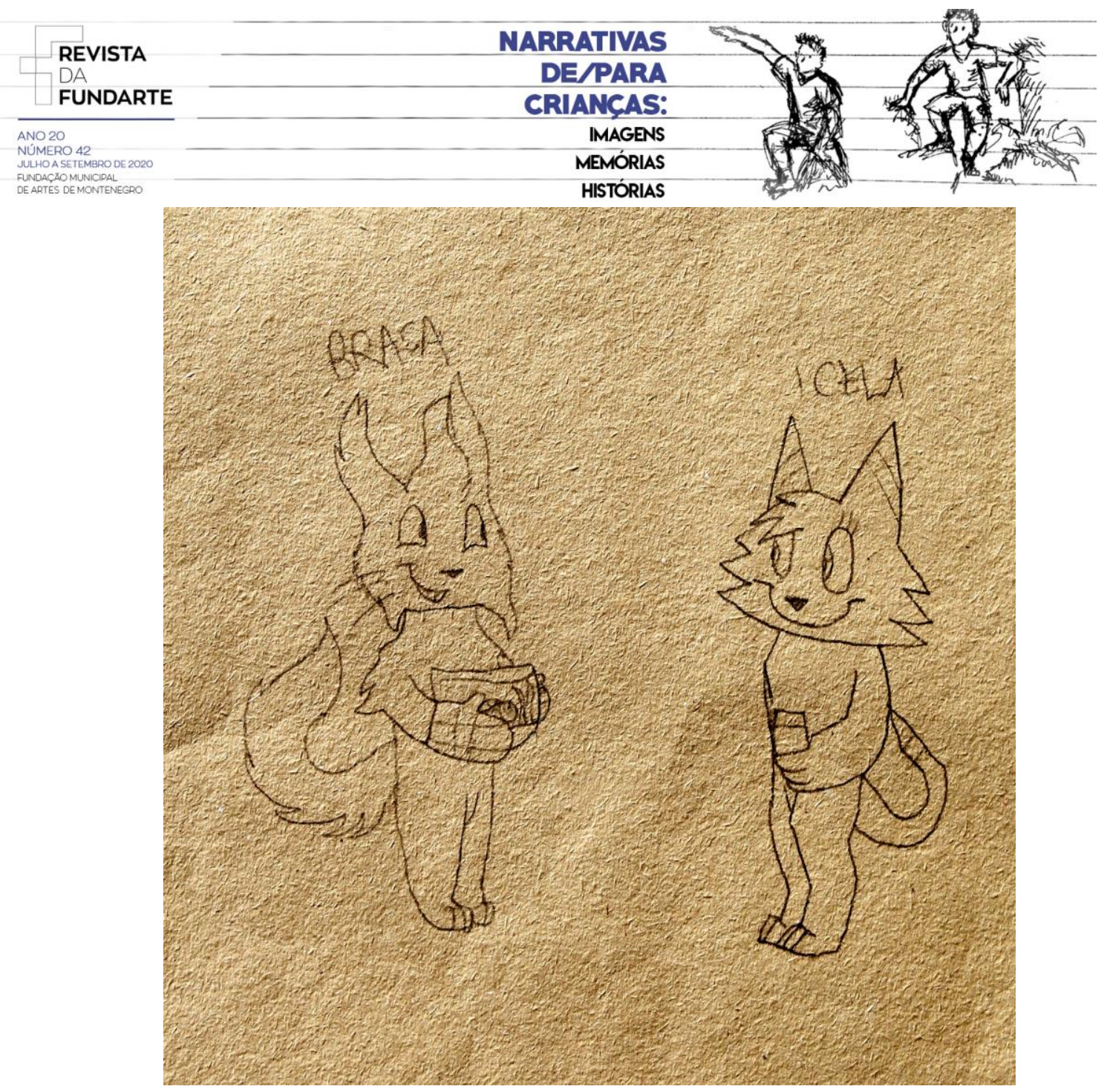

Ilustração 5. Desenho a lápis preto de Icela e Brasa. Desenho de Cristina. ( Fonte: Foto Arq. LHR)

As imagens nas folhas escolhidas para fazer o origami dos gatos tiveram impacto direto na narrativa, já que Icela foi confeccionada com uma folha que trazia a imagem de placas de gelo de um lago congelado, enquanto a folha de Brasa era uma abstração texturada em vermelho e laranja com traços amarelados, lembrando fogo. Cristina colou as duas figuras em origami num suporte azul e desenhou com lápis branco o interior de uma casa, com os potes de comida e água, uma bola, um ratinho sobre a linha de base. À esquerda, sangrando a borda, colocou uma mesinha com um aquário, diante de uma janela. A materialidade das folhas de gelo e fogo instigou as primeiras linhas narrativas, mas foi o detalhe do aquário na borda da folha que funcionou como solução do problema entre os personagens que queriam se abraçar. No desenho final à lápis sobre papel pardo, Cristina colocou frente a frente em posição quase três quartos os amigos Icela, com cílios, e Brasa.

REILY, Lucia Helena; LAPLAN, Adriana Lia Friszman de; DAINEZ, Débora. Texto e imagem em diálogo: modos de apropriação da cultura por uma jovem com transtorno do espectro do autismo Revista da FUNDARTE. Montenegro, p.01-32, ano 20, no 42, julho/setembro de 2020.

Disponível em: http://.seer.fundarte.rs.gov.br/index.php/RevistadaFundarte/index> 30 de setembro de 2020 


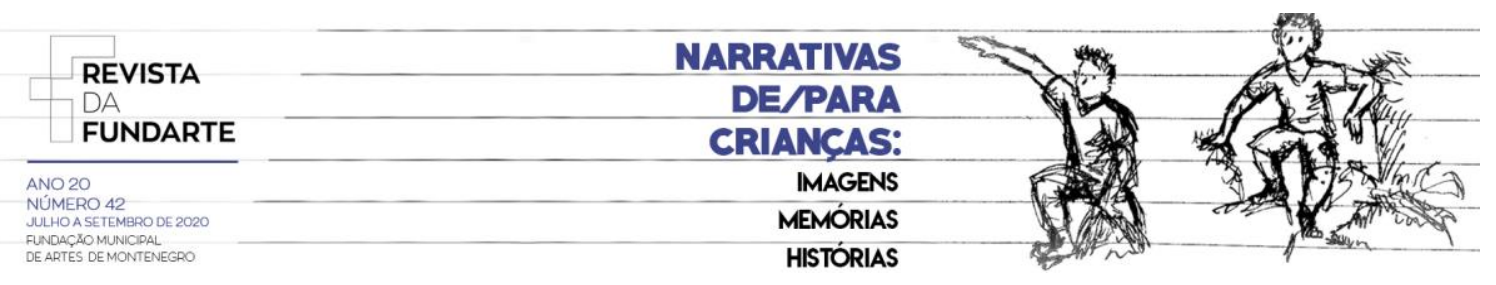

Aqui também as pupilas indicam o encontro do olhar dos dois. Destacam-se os seguintes detalhes que vieram do texto: Brasa usa luvas de cozinha para não aquecer o aquário onde está Felix. Icela traz o copo d'água. Cristina representou o momento anterior à transferência de Felix para o copo para que o abraço pudesse acontecer.

Na elaboração do diálogo textual, a criatividade emerge na reelaboração das relações entre Brasa e Icela. Cristina antecipa o perigo que o abraço encerra para a sua personagem de gelo e aceita a solução do conflito colocado pela incompatibilidade entre gelo e fogo, que a professora sugere. Ela assume também, uma postura atenta e cuidadosa em relação ao peixe Felix.

\section{Texto, imagem, origami, criatividade e imaginação}

Os textos foram todos escritos em letra bastão, por opção de Cristina. Eles trazem fortes marcas da oralidade, coerentes com o gênero "diálogo". Há, evidentemente, muitos erros de ortografia, como omissões, acréscimos ou inversões, mesmo em palavras conhecidas, como: ÁGUA (AUGA) e PEIXE (PEXIE). Alguns destes erros foram evidenciados durante as atividades e ela os corrigiu nos textos. Outros foram corrigidos quando Cristina digitou os textos no notebook em ocasião posterior. Quando ela tinha dúvidas sobre uma palavra, a professora soletrava ou escrevia e ela mesma buscava essa referência cada vez que a palavra reaparecia no texto.

Quanto à gramática, os textos também apresentam ausência de preposições ou uso de preposição incorreta. Algumas frases são bastante telegráficas, mas passíveis de compreensão na maior parte dos casos. Cristina faz uso eventual de pontuação, como ponto final, vírgula, ponto de exclamação e interrogação.

$O$ conjunto de desenhos e colagens coloca em evidência a diferença entre 0 estilo de desenho que Cristina desenvolveu ao longo de sua infância e a estética japonesa das dobraduras. O processo de confecção do origami implica precisão, sequência e respeito às regras. Essas propriedades contrastam com a fluidez linear 


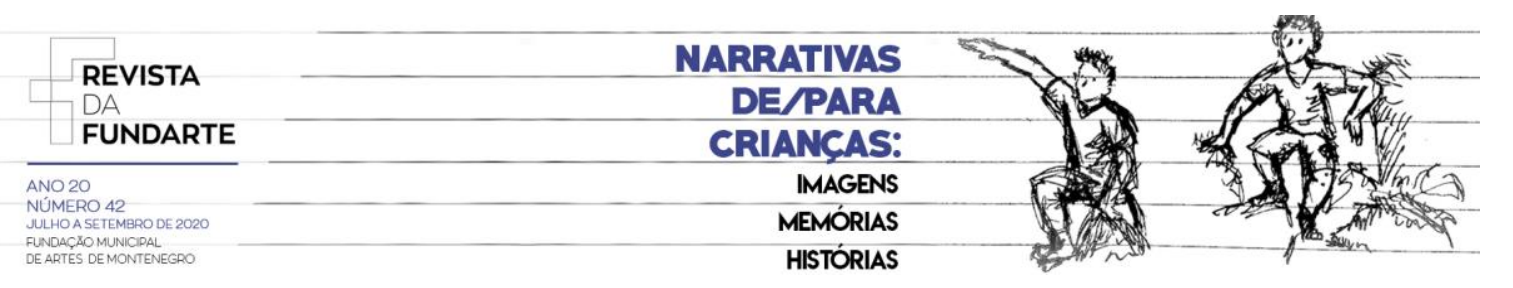

dos desenhos orgânicos de Cristina, que revelam forte influência da linguagem dos quadrinhos e filmes de animação produzidos pela mídia dirigida a crianças. Entretanto, o trabalho com origami foi uma experiência rica, para além de envolver a interpretação de instruções visuais em sequência. Na construção de cada dobradura, a figura que resulta das dobras demanda também um processo de interpretação de formas e configurações que diferenciam animais distintos. Quem cria o original usa seus processos criativos tanto quanto quem interpreta a figura imagina e abstrai para atribuir sentidos a ela.

Ainda, a leitura atenta dos escritos e a sua confrontação com os desenhos de Cristina autorizam algumas observações. A imaginação e a criatividade permitem à jovem elaborar e reelaborar o discurso. Ela recombina os elementos oriundos das diferentes linguagens e dos gêneros escritos e orais, assim como aqueles cuja origem pode ser identificada em filmes e no seu conhecimento sobre o mundo, de modo a sustentar a narrativa, agregando elementos novos. A situação imaginada é elemento indispensável da produção do desenho e do texto - é uma transformação das representações acumuladas, não limitadas pelas regras da lógica e pelas exigências do que deve parecer real (PETROVSKY, 2017).

As funções psíquicas como a atenção, a percepção, a memória e o pensamento se mostram articuladas com a lógica, quando Cristina traça os planos de ação dos personagens e prevê as consequências dessas ações. A função planejadora da linguagem se apresenta, nesses diálogos, de forma plena, apesar de que a escrita é ainda pouco convencional do ponto de vista da gramática e da sintaxe.

Chama à atenção a fluidez do diálogo, que contrasta com as características atribuídas às pessoas com TEA: dificuldade para estabelecer relações sociais, inadequação social, isolamento, dificuldade de perceber a intenção e o sentimento do outro... Os fragmentos aqui analisados, mesmo sendo pequenos excertos e trechos de textos maiores, permitem identificar um forte vínculo afetivo entre Cristina e a professora. Este se manifesta na construção conjunta dos diálogos, na troca de lugares e papéis, nas diferentes formas de participação da professora e da aluna, na 


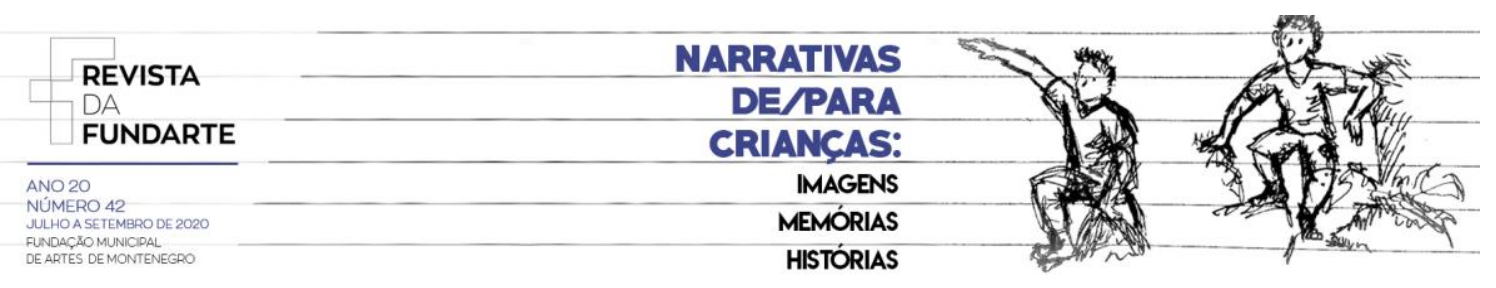

elaboração cada vez maior dos temas e no processo interlocutivo que se estabelece e se torna mais complexo.

Ao confrontamos a produção textual e imagética, a escrita e o desenho, notamos que os elementos que Cristina incluiu nas colagens sugeriram ideias para 0 diálogo textual, e por sua vez, o texto indicou elementos que seriam adicionados nos desenhos posteriores. Às vezes a professora puxava dos desenhos e colagens um detalhe que, então, passava a figurar como elemento da história. O diálogo entre as linguagens e a intensa circulação de sentidos, que envolve e integra as dimensões: afetiva, estética, cognitiva e social, descortina, assim, o processo de desenvolvimento e de apropriação cultural.

\section{Reflexões finais}

Em se assumindo a arte como o social em nós (VIGOTSKI, 1999), como atividade que aglutina sínteses psíquicas criadoras, sobressai a importância de perspectivar situações de desenvolvimento em que a criança, o adolescente, atuem em espaços intersubjetivos de criação do novo, produzindo narrativas a partir das realidades vividas e também de ficções imaginadas.

Quando analisamos o trabalho realizado com a adolescente em questão salta aos olhos o processo de construção de um espaço em que a imaginação e a criatividade podem emergir e mesmo conduzir o processo de aprendizagem e de aquisição de conhecimento. A pergunta que se coloca é: por que o sistema educativo ainda enfrenta tantas dificuldades para incluir pessoas como Cristina? A pergunta é retórica: sabemos a resposta! A nossa escola integra um sistema rígido, normativo e pouco sensível às necessidades, possibilidades e desejos de pessoas e grupos sociais. Mas, a experiência é contundente! Cristina frequentou durante vários anos as aulas de arte, sempre disposta a se relacionar com os outros participantes e a colaborar nas diversas atividades propostas.

É claro que as formas de organização da educação formal são muito diferentes daquelas em que foram conduzidas as aulas de Arte a que nos referimos. 


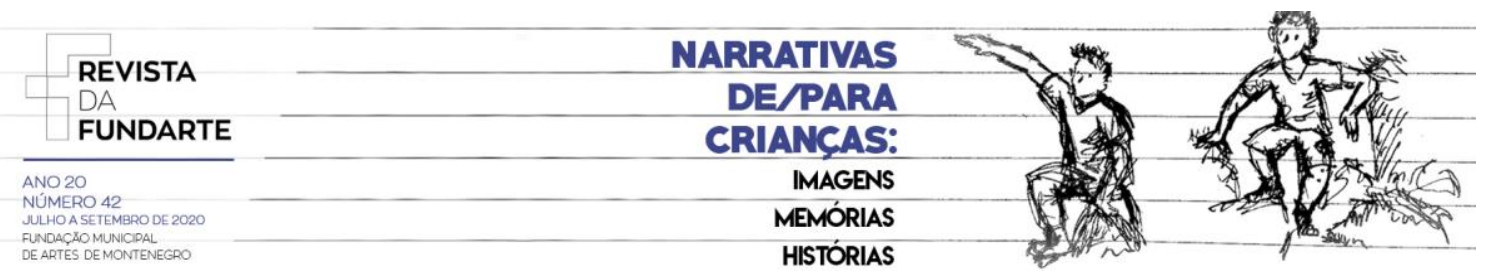

Só nos resta refletir sobre o potencial da vivência ética-estética para balizar os processos de ensino-aprendizagem e o desenvolvimento cultural da personalidade. Esses processos poderiam ser pensados como formas de promover a conexão entre as atividades artística (dimensão do sensível) e cognitiva (dimensão da razão), ampliando a visão de mundo. Trata-se, portanto, de introduzir a educação à vida, oferecendo mediações que possibilitem a elaboração criadora da realidade por meio do trabalho com a arte e com o conhecimento.

\section{Referências:}

BAKHTIN, M. Marxismo e filosofia da linguagem. São Paulo: Hucitec, 2006.

BOURSIN, D. Origami world: 40 fun paper-folding projects. Cincinatti: North Light Books, 2009.

CASSIRER, E. Ensaio Sobre o Homem. Uma introdução a uma filosofia da cultura humana. São Paulo: Martins Fontes, 1994.

CRUZ, M.N. Imaginário, Imaginação e relações sociais: reflexões sobre a imaginação como sistema psicológico. Caderno Cedes, v.35, 2015. p. 361-374.

FREEMAN, N.H.; COX, M. Visual order: the nature of development of pictorial representation. Londres: Cambridge University Press, 1985.

GOODNOW, J.J. Desenho de crianças. Lisboa: Moraes Editores,1979.

GOLOMB, C. The child's creation of a pictorial world. Berkeley: The University of California Press, 1992.

MAHEIRIE, K.; ZANELLA, A.V. Imagination and creative activity: ontological and epistemological principles of Vygotsky's contributions, In: RATNER, C.; SILVA, D.N.H. (Orgs.). Vygotsky and Marx: Toward a Marxist Psychology. London and New York: Routledge, 2017. p. 161-172.

MOLON, S. I. Constituição do sujeito volitivo e criativo: educação estética em Vygotsky, In: ZANELLA, A.V. et al. (Orgs.). Educação estética e constituição do sujeito: reflexões em curso. Florianópolis: NUP/CED/UFSC, 2007. p.121-130.

PETROVSKY, A.V. A imaginação. In. LONGAREZI, A.M.; PUENTES, R.V. (Orgs.), Ensino Desenvolvimental: Antologia, Livro 1. Uberlândia: EDUFU, 2017. p. 181-188. 


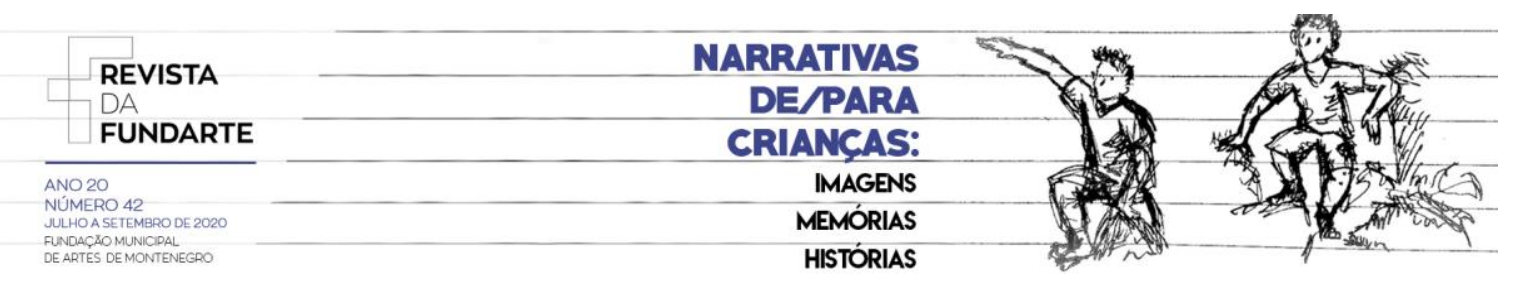

PINO, A. O social e o cultural na obra de Vigotski, Educação \& Sociedade. 21, (71), 2000. p.45-78.

PINO, A. A produção imaginária e a formação do sentido estético. Reflexões úteis para uma educação humana, Pro-Posições. 17, (2), 2006. p.47-69.

REILY, L. Armazém de imagens: ensaio sobre a produção artística de pessoas com deficiência. Campinas: Papirus, 2001.

ROGOFF, B. Los tres planos de la actividad sociocultural: apropiación participativa, participación guiada y aprendizaje. In.: WERTSCH, J.V.; DEL RIO, P.; ÁLVAREZ, A. (Eds.). La mente sociocultural: Aproximaciones teóricas y aplicadas. Madrid: Fundación Infancia y Aprendizaje, 1997. p.111-128.

ROGOFF, B. Cognition as a collaborative process, In.: KUHN, D.; SIEGLER, R. S. (Eds.). Handbook of child psychology: Cognition, perception, and language. New York: Wiley, 1998. p. 679-744.

SAWYER, R.K. Emergence in creativity and development. In.: SAWYER, R.K. et al. (Eds.). Creativity and Development. Oxford Scholarship online, 2012. p. 1-60. DOI: 10.1093/acprof:oso/9780195149005.003.0002.

SHUARE, M. A psicologia soviética: meu olhar. São Paulo: Terracota, 2017.

TATEO, L. What imagination can teach us about higher mental functions. In.: VALSINER, J. (Eds.). Psychology as the science of human being. Switzerland: Springer Internacional Publishing, 2016. p.149-164. DOI:10.1007/978-3-319-210940_9.

VIGOTSKI, L.S. Psicologia da Arte. São Paulo, Martins Fontes, 1999.

VIGOTSKI, L.S. Imaginação e criação na infância: ensaio psicológico. São Paulo: Ática, 2009.

VYGOTSKI, L. S. Obras Escogidas v. I. Trad. José Maria Bravo. Madrid: Visor Distribuciones, 1991.

VYGOTSKI, L. S. Obras Escogidas v. II. Trad. José Maria Bravo. Madrid: Visor Distribuciones, 1993.

VYGOTSKI, L. S. Obras Escogidas v. III. Trad. Lydia Kuper, Madrid: Visor Distribuciones, 1995. 


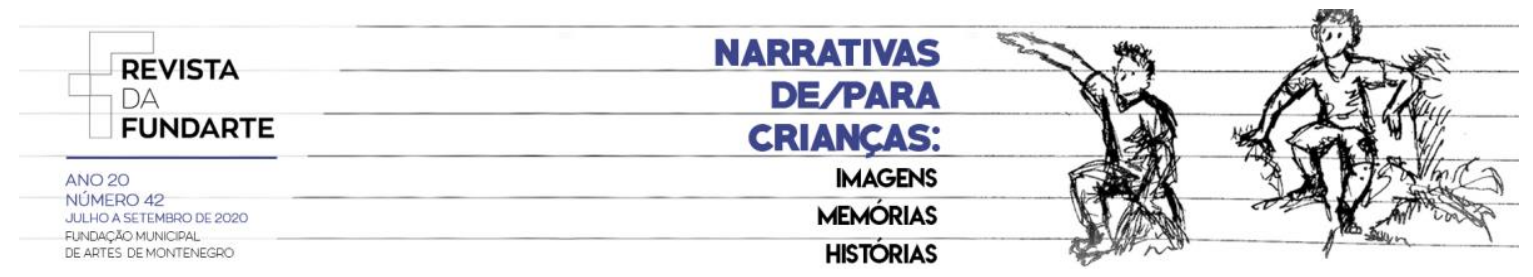

VYGOTSKI, L. S. Obras Escogidas v. IV. Trad. Lydia Kuper. Madrid: Visor Distribuciones, 1996.

VYGOTSKI, L.S. Obras Escogidas v.V. Trad. Júlio Guillermo Blank. Madrid: Visor Distribuciones, 1997.

REILY, Lucia Helena; LAPLAN, Adriana Lia Friszman de; DAINEZ, Débora. Texto e imagem em diálogo: modos de apropriação da cultura por uma jovem com transtorno do espectro do autismo Revista da FUNDARTE. Montenegro, p.01-32, ano 20, no 42, julho/setembro de 2020.

Disponível em: http://.seer.fundarte.rs.gov.br/index.php/RevistadaFundarte/index> 30 de setembro de 2020 